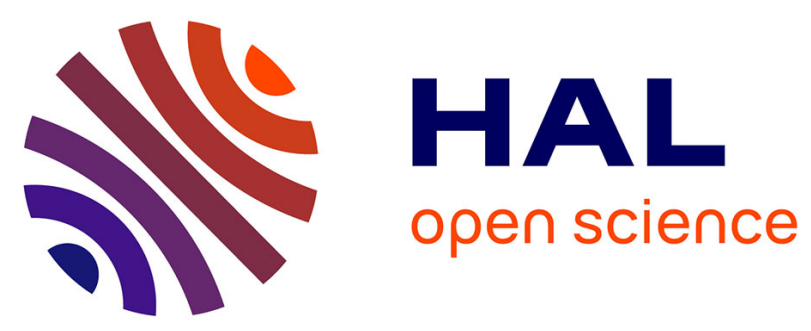

\title{
The influence of macrofaunal burrow spacing and diffusive scaling on sedimentary nitrification and denitrification: An experimental simulation and model approach
}

Franck Gilbert, Robert Curwood Aller, Stefan Hulth

\section{To cite this version:}

Franck Gilbert, Robert Curwood Aller, Stefan Hulth. The influence of macrofaunal burrow spacing and diffusive scaling on sedimentary nitrification and denitrification: An experimental simulation and model approach. Journal of marine research, 2003, vol. 61, pp. 101-125. 10.1357/002224003321586426 . hal-00780276

\section{HAL Id: hal-00780276 \\ https://hal.science/hal-00780276}

Submitted on 23 Jan 2013

HAL is a multi-disciplinary open access archive for the deposit and dissemination of scientific research documents, whether they are published or not. The documents may come from teaching and research institutions in France or abroad, or from public or private research centers.
L'archive ouverte pluridisciplinaire HAL, est destinée au dépôt et à la diffusion de documents scientifiques de niveau recherche, publiés ou non, émanant des établissements d'enseignement et de recherche français ou étrangers, des laboratoires publics ou privés. 


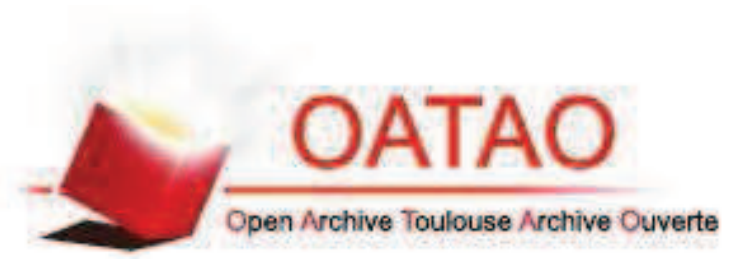

\section{Open Archive Toulouse Archive Ouverte (OATAO)}

OATAO is an open access repository that collects the work of Toulouse researchers and makes it freely available over the web where possible.

This is an author-deposited version published in: http://oatao.univ-toulouse.fr/ Eprints ID: 6103

To link to this article: DOI: $10.1357 / 002224003321586426$

URL: http://dx.doi.org/10.1357/002224003321586426

To cite this version: Gilbert, Franck and Aller, Robert Curwood and Hulth, Stefan The influence of macrofaunal burrow spacing and diffusive scaling on sedimentary nitrification and denitrification: An experimental simulation and model approach. (2003) Journal of Marine Research, vol. $61\left(\mathrm{n}^{\circ} 1\right)$. pp. 101-125. ISSN 0022-2402

Any correspondence concerning this service should be sent to the repository administrator: staff-oatao@,listes.diff.inp-toulouse.fr 


\title{
The influence of macrofaunal burrow spacing and diffusive scaling on sedimentary nitrification and denitrification: An experimental simulation and model approach
}

\author{
by Franck Gilbert ${ }^{1}$, Robert C. Aller ${ }^{2}$ and Stefan Hulth ${ }^{3}$
}

\begin{abstract}
The influence of burrow spacing on sedimentary nitrification and denitrification was simulated experimentally using sediment plugs of different thicknesses immersed in aerated seawater reservoirs. Different plug thicknesses mimic different distances between oxygenated burrow centers and produce similar changes in aerobic-anaerobic reaction balances as a function of diffusive transport scaling. The thicknesses used were roughly equivalent to transport scales (interburrow spacing) that could be produced by burrow abundances of $\sim 400$ to $50,000 \mathrm{~m}^{-2}$, depending on burrow lumen radii (e.g., $0.05-1 \mathrm{~cm}$ ). Following the exposure of anoxic sediment plugs to aerated water, an efficient aerobic nitrification zone was established within the first $\sim 2-3$ millimeters of sediment. At pseudo-steady state, the thinnest plug $(2 \mathrm{~mm})$ simulating highest burrow density, was entirely oxic and the denitrification rate nil. Denitrification was stimulated in anoxic regions of the thicker plugs $(5,10$, and $20 \mathrm{~mm})$ compared to the initial value in experimental sediment. Maximum nitrification rates and the highest denitrification/nitrification ratio between oxic nitrification and adjacent denitrification zones occurred for the intermediate plug thickness of $5 \mathrm{~mm}$. Of the oxic/anoxic composites, the thickest plug showed the least efficient coupling between nitrification/denitrification zones (lowest denitrification/nitrification ratio). Both the thickness of the oxic layer and the total net remineralization of dissolved inorganic $\mathrm{N}$ varied inversely with plug thickness. A set of diffusionreaction models was formulated assuming a range of possible nitrification kinetic functions. All model forms predicted optimal nitrification-denitrification and ammonification-denitrification coupling with relative oxic-anoxic zonation scales comparable to intermediate plug thicknesses (5-6 mm). However, none of the commonly assumed kinetic forms for nitrification could produce the observed $\mathrm{NO}_{3}^{-}$profiles in detail, implying that natural sediment populations of nitrifiers may be less sensitive to $\mathrm{O}_{2}$ than laboratory strains. Our experimental and model results clearly show that rates of $\mathrm{N}$ remineralization and the balance between stimulation/inhibition of denitrification are highly dependent on sedimentary biogenic structure and the particular geometries of irrigated burrow distributions.
\end{abstract}

1. Laboratoire d'Océanographie et de Biogéochimie (COM), UMR CNRS 6535, Faculté de Luminy, Case 901, F-13288 Marseille Cedex 9, France.e-mail: gilbert@com.univ-mrs.fr

2. Marine Sciences Research Center, State University of New York at Stony Brook, Stony Brook, New York, 11794-5000, U.S.A.

3. Analytical and Marine Chemistry, Göteborg University, SE-41296 Göteborg, Sweden. 


\section{Introduction}

Sedimentary denitrification is one of the major components of the marine nitrogen cycle (e.g. Seitzinger, 1988; Seitzinger and Giblin, 1996). Denitrification consumes dissolved nitrate, remineralizes $\mathrm{C}_{\text {org }}$, and exports gaseous nitrogen to the atmosphere (Knowles, 1982). Although an anaerobic process, denitrification has an antipodal interaction with $\mathrm{O}_{2}$ in sediments. Oxygen inhibits the enzymes of denitrification (Firestone et al., 1980) but also stimulates sedimentary nitrification which usually provides the major source of $\mathrm{NO}_{3}^{-}$ for denitrification (Billen, 1982). Bioturbation of sedimentary deposits typically generates close juxtapositions of oxic and anoxic microenvironments around biogenic structures and strongly influences both nitrification and denitrification. There is often a general stimulatory effect of macrobenthic activity, and particularly bioirrigation, on sedimentary nitrification and denitrification (Sayama and Kurihara, 1983; Kristensen and Blackburn, 1987; Henriksen and Kemp, 1988; Pelegri et al., 1994; Mayer et al., 1995; Rysgaard et al., 1995; Gilbert et al., 1998). Field measurements have demonstrated that denitrification rates can also vary inversely with bioirrigation intensity at the highest irrigation rates (Berelson et al., 1998). Direct comparison of the causes and magnitudes of reported stimulation (from 114 to $950 \%$ ) or inhibition is virtually impossible because both the macrofaunal species and the organism abundances are distinct to each study. Species-specific burrow properties such as mucous secretions, burrow wall construction, or irrigation behavior are known to affect nitrification and denitrification, and require characterization of individual species (Aller et al., 1983; Kristensen et al., 1985, 1991; Mayer et al., 1995). In contrast, the likely effects of population abundance or burrow spacing, and the corresponding changes in transport-reaction structure, can in principle be isolated by geometrically simulating variations in the distances between burrows.

A primary effect of irrigated tubes or burrows is to create diffusive sources or sinks for pore water solutes within otherwise isolated portions of sedimentary deposits. Stagnant burrows have no discernable effects on pore water distributions, and frequent irrigation is required to maintain local oxygenated conditions and diffusive concentration gradients between burrow lumen and surrounding sediment pore water (Aller, 1984; Kristensen, 1988; Boudreau and Marinelli, 1994). In order to examine the general impacts of irrigated burrows and the associated macro-transport structure on nitrification and denitrification independently of species-specific effects, we carried out an experiment in which plugs filled with sediment were exposed continuously to oxygenated overlying water (e.g. Aller and Mackin, 1989). Our experimental design was based on the concept that the characteristic scales of diffusion, and thus transport-reaction patterns within the bioturbated zone of muddy deposits, are determined in large part by the time-averages of size and effective spacing of irrigated burrow structures (Aller, 2001). By simply varying plug thickness (L; Fig. 1A), we simulated different spacings between irrigated burrows and the resulting degrees of sediment oxygenation, thereby altering the relative extent of coupled nitrification and denitrification zones, and mimicing changes in burrow density (Aller and Aller, 1998; Hulth et al., 1999).

Our experimental setup allowed us to simulate a wide range of effective burrow 
A

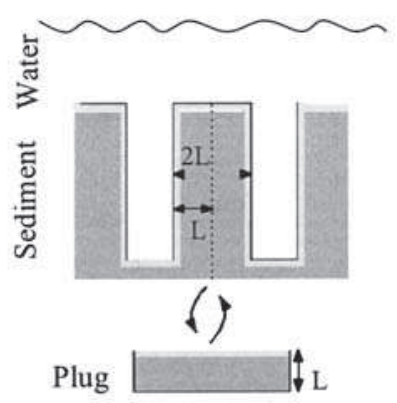

B

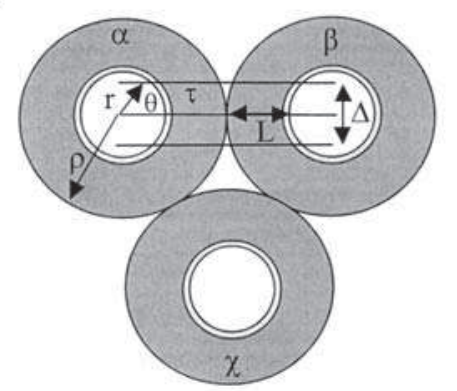

C

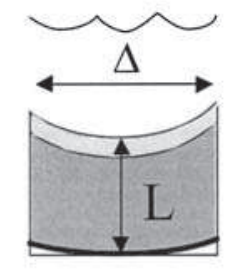

D

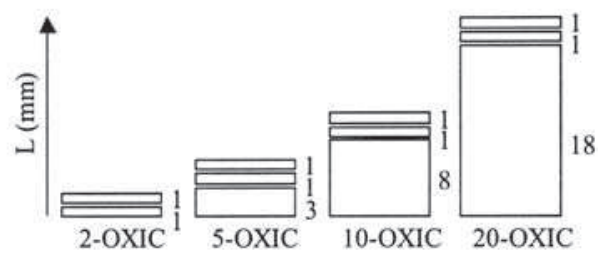

Figure 1. (A) Schematic diagram of two idealized, identical burrow structures shown separated in the axial plane at a particular time by a constant characteristic distance $2 L$. Light areas indicate oxygenated zones, dark are anoxic. In reality, the distance $2 L$ and axial orientation vary as a complex function of space and time, however, the basic physical interactions between irrigation centers are represented in the idealized geometry. (B) Idealized view perpendicular to axis of hexa-net packed burrows or burrow structure microenvironments $(\alpha, \beta, \chi)$ having burrow lumen radius $r$. In this case the orientation of the plane is parallel to the sediment surface in (A) but may be thought as having an arbitrary orientation within a sedimentary deposit. Because sedimentary solutes must achieve a concentration minimum or maximum at distance $\sim L$ (no net flux) between identical structures, a characteristic diffusion scale $L=(\rho-r)$ can be considered along the segment $\tau$ between any two burrow centers. This diffusive scaling within the plane applies roughly to the swath of sediment $\Delta=2 r \sin (\theta)$ with a fractional variation around $L$ of $\sim r(1-\cos$ $(\theta)) /(\rho-r)$. Because irrigated microenvironments are never exactly identical, the scaling $L$ may lie away from the midpoint between any two burrow centers. (C) The effect of variable interburrow spacing on the characteristic diffusion scale $(L)$ can be simulated approximately by sections of planar sediment exposed on one surface and with sealed bottoms (i.e., no net flux basal condition). The scale $\Delta$ is not critical to examining the effect of scale $L$ per se but is an indication of spatial extent over which a given approximation applies (smaller as $r / \rho \rightarrow 0$ ). The planar diffusion and one dimensional scale approximation to radial diffusion distributions becomes most accurate as $r / \rho \rightarrow 1$. (D) Different thicknesses (lengths) of plugs were used in the present experiments to mimic different time-averaged burrow spacings which might occur at various locations within bioturbated sediments ( $L$ values are expressed in millimeters). The upper $2 \mathrm{~mm}$ of plugs were divided at $1 \mathrm{~mm}$ intervals by use of stacked rings of $1 \mathrm{~mm}$ thickness, allowing rapid accurate sectioning at time of sampling. 
abundances from medium $\left(\sim 400 \mathrm{~m}^{-2}\right)$ to high density $\left(\sim 50,000 \mathrm{~m}^{-2}\right.$, e.g., Ronan, 1978 ; Aller et al., 2002), depending on the exact burrow lumen radii (e.g., $0.05-1 \mathrm{~cm})$. A characteristic diffusive transport scale $L$ resulting from a particular burrow abundance is given approximately by $(\rho-r)$, where $\rho \sim 1 / \sqrt{\pi N}(N=$ burrow abundance per area) and $r=$ radius of the irrigated burrow center or lumen (Fig. 1). The use of a planar transport geometry in our experimental manipulations does not exactly mimic the radial or irregular diffusive coupling between reaction zones typically found around burrows or between sectors of individual burrows, but it is sufficient to demonstrate the basic principles involved (Fig. 1).

\section{Materials and methods}

a. Experimental procedure

Surface $(0-2 \mathrm{~cm})$ muddy sediment and overlying seawater were collected using a Ponar grab at station $\mathrm{P}(\sim 14 \mathrm{~m})$ in central Long Island Sound, USA, during June 1997 (see: Gérino et al., 1998; for station P description; salinity $24-28$, silt-clay, $\sim 2 \%$ organic C, $\sim 3 \% \mathrm{CaCO}_{3}$ ). All materials used in the laboratory for sampling, storage and chemical analyses were precleaned with $\mathrm{HCl}$ and rinsed with double distilled water and seawater. Experimental containers for holding sediment were made of sections of PVC pipes cut into rings (two diameter sizes: small, $2.1 \mathrm{~cm}$ ID; large, $5.2 \mathrm{~cm} \mathrm{ID).} \mathrm{First,} \mathrm{1,} \mathrm{3,} 8$ and $18 \mathrm{~mm}$ length PVC rings were fixed on individual circular PVC base sheets. Then, one or two additional $1 \mathrm{~mm}$ thick rings were stacked on the basal rings in order to obtain 4 groups of sediment plugs having total thicknesses (lengths) of: 2, 5, 10 and $20 \mathrm{~mm}$ (Fig. 1B). A second group of polycarbonate plug containers $(2.85 \mathrm{~cm}$ ID) of equivalent total thicknesses (lengths) was used for the measurement of denitrification activity only.

All plugs were filled with sediment that had been sieved through a $0.5 \mathrm{~mm}$ nylon mesh (no added water) to remove macrofauna and homogenized by hand stirring under $\mathrm{N}_{2}$ in a glove bag. Sets of plugs having the same thickness (single set $=9$ large PVC plugs, 1 small PVC plug and 4 polycarbonate plugs; Fig. 2), were then submersed in large polycarbonate reservoirs containing 15.41 of $0.2-\mu \mathrm{m}$ filtered seawater continuously purged with watersaturated air. These plug sets were termed 2-OXIC, 5-OXIC, 10-OXIC, 20-OXIC respectively, depending on thickness (2-, 5-, 10-, 20-mm). As a control, another reservoir without sediment plugs (BLANK) was also filled with filtered and aerated seawater. Subsamples of the experimental sediment were dried to constant weight at $60^{\circ} \mathrm{C}$ for determination of saturated porosity.

Water reservoirs were continuously stirred by a centrally located magnetic stir bar at a rate slightly below that necessary to suspend sediment (in order to minimize diffusive boundary layers). Overlying water ( $\sim 20 \mathrm{ml})$ from each container was periodically sampled (after $0,1,3,5,7,9$ and 13 days) with a syringe and analyzed. After 13 days, plugs were removed from reservoirs, sediment layers were sliced by sliding off individual rings of a stack, placing the sediment into plastic syringes, and porewater separated from the sediment (large plugs) by squeezing in individual syringe presses. There was no discern- 


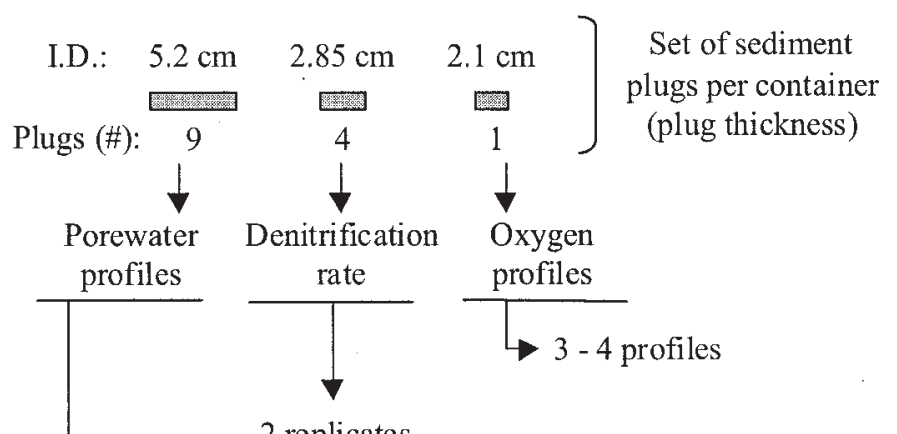

2 replicates

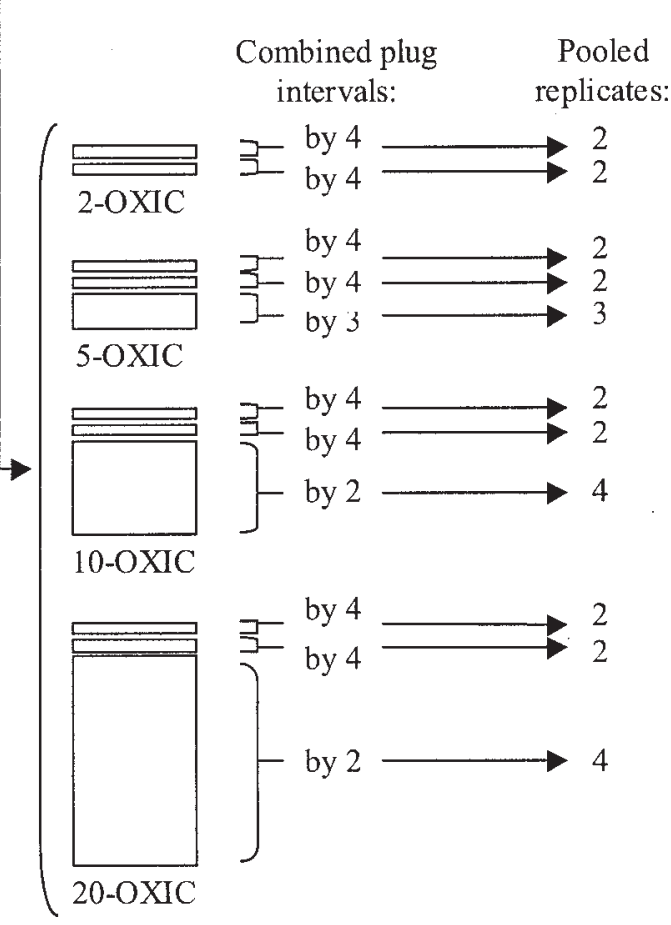

Figure 2. Schematic diagram of experimental setup. Inner diameters (I.D.) and numbers of plugs used for the different measurements are indicated. Each container held a complete set of plugs having a single overall thickness (14 plugs). The depth interval sampling scheme for pore water is shown for each type of plug of a given overall thickness. The equivalent depth intervals from several plugs having the same total thickness were combined into single samples for pooled analysis. For example, the top $0-1 \mathrm{~mm}$ of sediment from 4 separate plugs in the $2 \mathrm{~mm}$ thick plug container was combined into a single pooled sample. There were 2 such combined samples (composed of 4 plugs each) representing the sampling of pore water from 8 plugs overall.

able compaction or expansion of sediment relative to starting thicknesses within individual plugs. Pore water sampling and separations were completed within several minutes following removal of individual plugs from water reservoirs. Pore water from particular 
depth intervals in multiple plugs of the same length were combined as necessary to obtain sufficient sample for analyses, resulting in 2 pooled replicates for each of the $1 \mathrm{~mm}$ intervals and up to 4 replicates for the thicker basal sections (Fig. 2).

\section{b. Chemical analyses: denitrification}

Denitrification rates were assessed using the acetylene-blockage method. Sediment subsamples $(0.7 \mathrm{ml}$ for the 2 -mm thick plugs, $1 \mathrm{ml}$ for the others) from duplicate polycarbonate plugs were transferred into $5 \mathrm{ml}$ tubes with $2 \mathrm{ml}$ of seawater from each corresponding reservoir. Seawater was supplemented with chloramphenicol (final concentration: $1 \mathrm{~g} \mathrm{~L}^{-1}$ ) to prevent new bacterial growth during incubation and to extend the period of linear $\mathrm{N}_{2} \mathrm{O}$ accumulation (Tiedje et al., 1989). The tubes were sealed with rubber stoppers and anaerobic conditions were obtained by flushing $\mathrm{N}_{2}$ through the tube for $2 \mathrm{~min}$. Acetylene, which inhibits the reduction of $\mathrm{N}_{2} \mathrm{O}$ to $\mathrm{N}_{2}$ (Balderston et al., 1976), was injected in the gas phase (final pressure: $15 \mathrm{kPa}$ ) and the tubes were vortexed. Samples were incubated in the dark at experimental temperature for $0,1,3,5$ and $8 \mathrm{~h}$. After incubation, each tube was fixed with $0.1 \mathrm{ml}$ of $1 \mathrm{M} \mathrm{HgCl}_{2}$ solution to terminate reaction.

Nitrous oxide in the tubes was determined by gas chromatography (HP5890, Series II) using an electron capture detector and an automatic injector (Dani HSS 86.50). The nitrous oxide detection limit was $100 \mathrm{nM}$. Chromatographic operating conditions: oven temperature: $50^{\circ} \mathrm{C}$; injector temperature: $150^{\circ} \mathrm{C}$; detector temperature: $260^{\circ} \mathrm{C}$. Nitrogen was used as carrier gas $\left(20 \mathrm{ml} \mathrm{min}^{-1}\right)$ for the ECD GC system.

\section{c. Chemical analyses: oxygen, nutrients}

The smaller PVC plugs were used for the determination of oxygen distribution using a Clark-style combination microelectrode (Revsbech et al., 1980). The electrode was standardized in seawater saturated with air or nitrogen at $22^{\circ} \mathrm{C}$, and the zero value also checked by insertion of the electrode deep into a separate container of anoxic sediment. A gas exchange FIA-technique using conductivity detection as described by Hall and Aller (1992) was used to determine ammonium concentrations. Concentrations of nitrite and nitrate were determined using standard colorimetric methods (Strickland and Parsons, 1972) applied to a miniaturized flow injection system. Analytical precisions were generally $\sim 2-5 \%$ SD and less than variability between plug samples.

\section{Results}

\section{a. Overlying water $N$-compound changes with time}

$\mathrm{N}$-compound concentrations changed regularly both in magnitude and speciation as a function of time in the different overlying water reservoirs (Fig. 3). Reservoirs were continuously aerated and stirred. The basic relative patterns of DIN $\left(\mathrm{NH}_{4}^{+}, \mathrm{NO}_{2}^{-}, \mathrm{NO}_{3}^{-}\right)$in each reservoir were the same. These relative changes consisted of an initial release and rapid buildup of $\mathrm{NH}_{4}^{+}$, followed by progressive oxidation and successive conversion to $\mathrm{NO}_{2}^{-}$and $\mathrm{NO}_{3}^{-}$, and then a continued, but slowed buildup of total DIN, largely as $\mathrm{NO}_{3}^{-}$, 

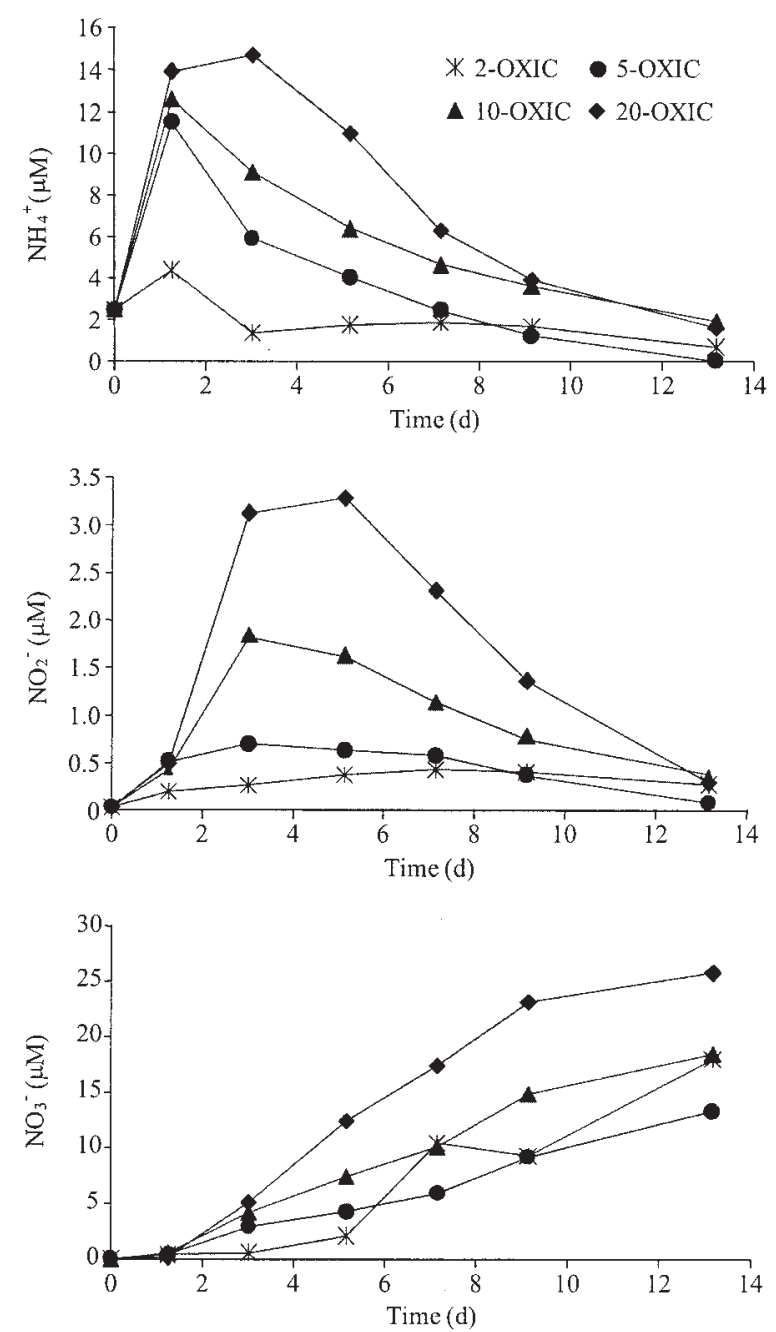

Figure 3. Nitrogen compound $\left(\mathrm{NH}_{4}^{+}, \mathrm{NO}_{2}^{-}\right.$and $\left.\mathrm{NO}_{3}^{-}\right)$concentrations as a function of time in overlying water reservoirs for the different sediment plug thicknesses.

over the remainder of the experiment. The magnitude of DIN concentrations obtained in each case depended directly on the quantity of sediment present in the reservoir, i.e. plug thickness (Fig. 3). These general patterns are typical of the classically recognized successions of DIN speciation observed during remineralization (ammonification) and nitrification.

In detail: following initial exposure of oxygenated water to anoxic sediment plugs, $\mathrm{NH}_{4}^{+}$ concentrations increased sharply until the second day, reaching maxima of 4.38 to $13.90 \mu \mathrm{M}$ for 2-OXIC and 20-OXIC respectively, and then decreased exponentially to final concentrations after 13 days of $<0.04$ (detection limit) to $1.94 \mu \mathrm{M}$, all lower than the 
Table 1. Concentrations in the sediment and overlying water and sediment denitrification rate prior to the open plug incubations (mean, $n=2$ ).

$\begin{array}{lcccc} & \begin{array}{c}\Sigma \mathrm{NO}_{3}^{-}+\mathrm{NO}_{2}^{-} \\ (\mu \mathrm{M})\end{array} & \begin{array}{c}\mathrm{NO}_{2}^{-} \\ (\mu \mathrm{M})\end{array} & \begin{array}{c}\mathrm{NH}_{4}^{+} \\ (\mu \mathrm{M})\end{array} & \begin{array}{r}\text { Denitrification rate } \\ \left(\mu \mathrm{mol} \mathrm{N} \mathrm{O} \mathrm{L}^{-1} \mathrm{~d}^{-1}\right)\end{array} \\ \text { Porewater } & 1.5 & 0.6 & 640 & 37.7 \\ \text { Overlying water } & 0.0 & 0.03 & 2.5 & -\end{array}$

starting value $(2.5 \mu \mathrm{M}$; Table 1$)$. Although total DIN continued to increase in the overlying water over time, the initially released $\mathrm{NH}_{4}^{+}$pools were progressively oxidized first to $\mathrm{NO}_{2}^{-}$ and then $\mathrm{NO}_{3}^{-}$, with the intermediate $\mathrm{NO}_{2}^{-}$showing maximum concentrations during the initial stages of conversion (approximately three days). Final concentrations ranged between $0.03 \mu \mathrm{M}$ (initial concentration; Table 1) and $0.5 \mu \mathrm{M}$. $\mathrm{NO}_{3}^{-}$concentrations were quite stable the first day and then continuously increased to reach final concentrations from $13.45 \mu \mathrm{M}$ (5-OXIC) to $26.08 \mu \mathrm{M}$ (20-OXIC) (Fig. 3). In the control container without sediment (BLANK), final concentrations were 1.02, 0.4 and $4.01 \mu \mathrm{M}$ for $\mathrm{NH}_{4}^{+}, \mathrm{NO}_{2}^{-}$, and $\mathrm{NO}_{3}^{-}$, respectively.

\section{b. Oxygen penetration patterns}

Oxygen progressively diffused into the initially anoxic sediment plugs and reached pseudo-steady state penetration depths. After the $13 \mathrm{~d}$ incubation, $\mathrm{O}_{2}$ profiles in the sediments showed typical diffusive patterns with the $\mathrm{O}_{2}$ penetration decreasing inversely with increasing sediment thickness (mean of 3-4 individual profiles) (Fig. 4A). For example, the $\mathrm{O}_{2}$ concentration at $2 \mathrm{~mm}$ depth was $152,54,28$ and $19 \mu \mathrm{M}$ for 2-OXIC, 5-OXIC, 10-OXIC and 20-OXIC, respectively.

\section{c. Sedimentary DIN-compound profiles}

The sediment in all plugs was initially homogenized and had identical, vertically constant concentrations of $\mathrm{NH}_{4}^{+}, \mathrm{NO}_{2}^{-}$, and $\mathrm{NO}_{3}^{-}$(Table 1). These initial concentration profiles changed rapidly following continuous exposure to oxygenated water. Oxic and anoxic sediment zones were established, the relative scales of which depended on total sediment thickness. In contrast to the $2 \mathrm{~mm}$ plugs, the partial penetration of $\mathrm{O}_{2}$ in the cases of the 5,10 , and $20 \mathrm{~mm}$ plug sets resulted in varying relative thicknesses of oxic and anoxic redox zones (Fig. 4B). At the time of final sampling, all $\mathrm{N}$ reaction patterns and corresponding concentration distributions were expected to be at a pseudo-steady state (see subsequent model calculations). The $2 \mathrm{~mm}$ plug set was completely oxidized, and the DIN vertical distributions were characterized by low $\mathrm{NH}_{4}^{+}$and high $\mathrm{NO}_{3}^{-}$concentrations, reflecting net nitrification throughout the entire plug and a net $\mathrm{NO}_{3}^{-}$flux to the overlying water (Fig. 5).

The surface of each of the thicker plug sets was clearly dominated by nitrification, as indicated by maximum $\mathrm{NO}_{3}^{-}$concentrations in either the upper 1 or $2 \mathrm{~mm}$ (Fig. 5). These $\mathrm{NO}_{3}^{-}$concentrations exceeded overlying water concentrations, demonstrating a diffusive 

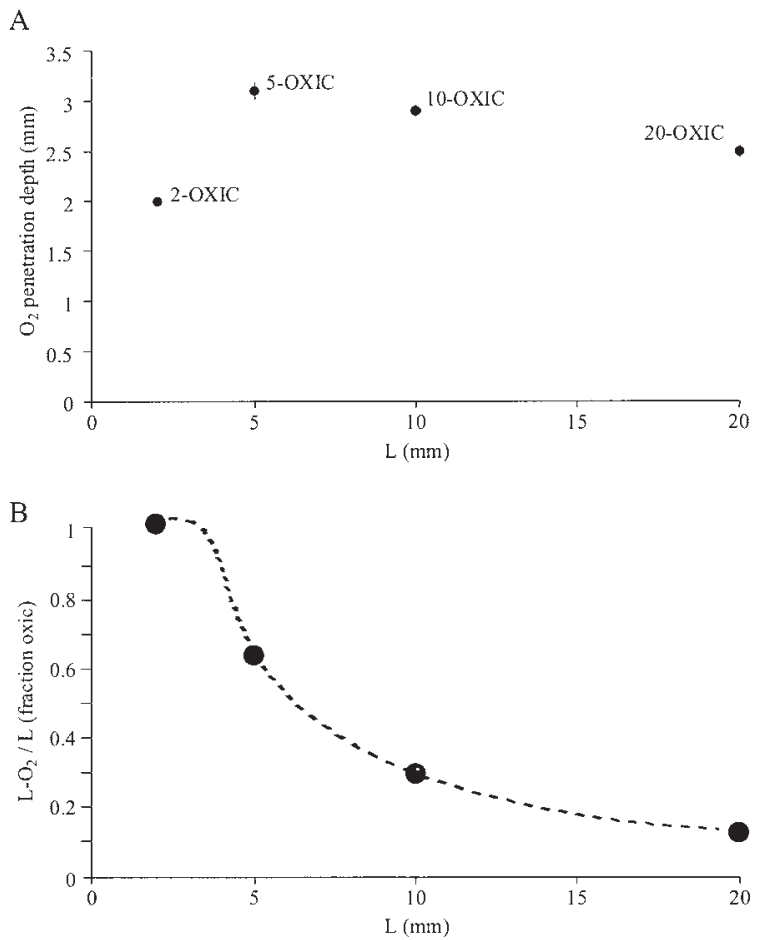

Figure 4. (A) Measured $\mathrm{O}_{2}$ penetration depth (mean $\pm \mathrm{SD}$ ) and (B) fraction of total plug thickness that is oxic as a function of plug thickness $(L)$ (dotted line represents interpretive pattern).

flux of $\mathrm{NO}_{3}^{-}$into overlying water. Basal anoxic sediment zones had lower $\mathrm{NO}_{3}^{-}$concentrations than overlying oxic zones, indicating downward diffusion of $\mathrm{NO}_{3}^{-}$and net denitrification. $\mathrm{NH}_{4}^{+}$profiles demonstrated buildup at the bases of each plug set and obvious depletion in the surface 1-2 mm, mirroring surficial $\mathrm{NO}_{3}^{-}$increases. Averaged $\mathrm{NH}_{4}^{+}$ concentrations in plugs were all lower than the initial pore water $\mathrm{NH}_{4}^{+}$concentration, consistent with both diffusive loss of $\mathrm{NH}_{4}^{+}$to overlying water during transient equilibration conditions (Fig. 3), and also with the consumption of $\mathrm{NH}_{4}^{+}$in the oxic zone during sedimentary nitrification. The profiles of $\mathrm{NH}_{4}^{+}$concentration varied regularly with plug thickness (length), attaining the least overall concentrations in the $2 \mathrm{~mm}$ plug set and highest in the basal regions of the $20 \mathrm{~mm}$ plugs.

\section{d. Direct measures of sediment denitrification rates}

Directly measured denitrification rates showed differences with the plug thickness (Fig. 6). The rate measured in the thinnest, completely oxic plug (less than $0.5 \mu \mathrm{mol}$. $\mathrm{N}_{2} \mathrm{O} \mathrm{L}^{-1} \mathrm{~d}^{-1}$ ) showed a decrease with respect to the initial homogenized sediment rate (37.7 $\mu \mathrm{mol} . \mathrm{N}_{2} \mathrm{O} \mathrm{L}^{-1} \mathrm{~d}^{-1}$, immediately following homogenization). In the remaining plug sediments, denitrification rates in the anoxic zone were increased $\sim 4$ to 10 times the initial bulk value (Table 1 ). 

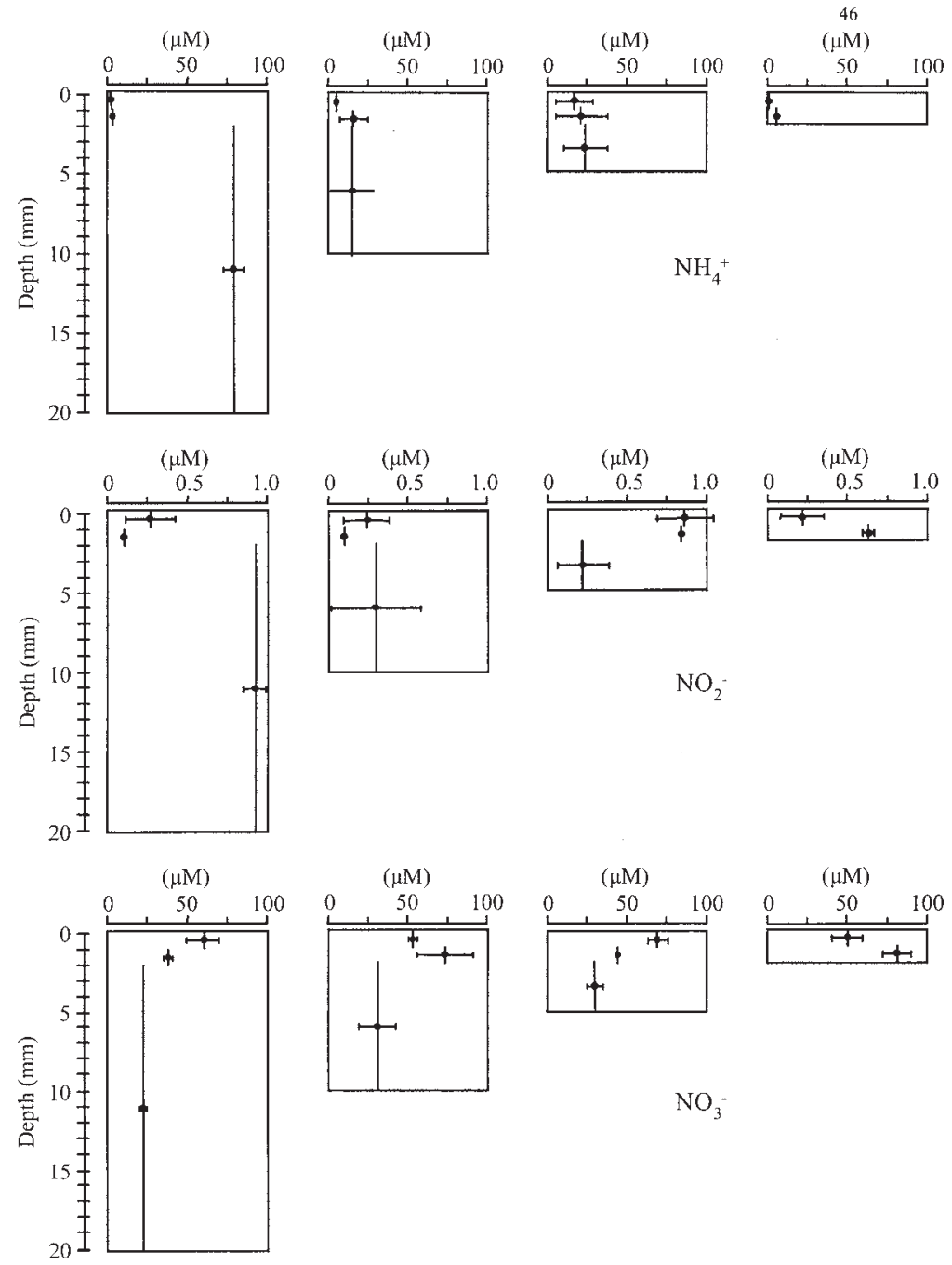

$\mathrm{NO}_{3}^{-}$

Figure 5. Nitrogen compound concentration (mean $\pm \mathrm{SD}$ ) profiles in the different sediment plugs at the end of experimentation. Top: $\mathrm{NH}_{4}^{+}$, middle: $\mathrm{NO}_{2}^{-}$, and bottom: $\mathrm{NO}_{3}^{-}$. For the $0-1$ and $1-2 \mathrm{~mm}$ layers, $n=2$, for the $2-5 \mathrm{~mm}$ layer, $n=3$, and for the $2-10$ and 2-20 mm layers, $n=4$.

\section{e. Mass balance estimates of $N$ remineralization}

Minimum estimates of total net $\mathrm{N}$ remineralization rates in the individual plug sets can be obtained from the change between the total mass of DIN present initially and that present at the end of the experiment in each plug set microcosm. Losses of $\mathrm{N}$ by denitrification, formation of dissolved organic $\mathrm{N}$ during decomposition, or transient uptake into biomass in this case are ignored. The minimum rate of dissolved $\mathrm{N}$ production $\left(R_{N}\right)$, assumed equivalent to the ammonification rate over a time interval $\Delta t$, is:

$$
R_{N}=\left[\left(N_{o w}(\Delta t)+N_{p w}(\Delta t)\right)-\left(N_{o w}(0)+N_{p w}(0)\right)\right] / V_{p w} \Delta t
$$




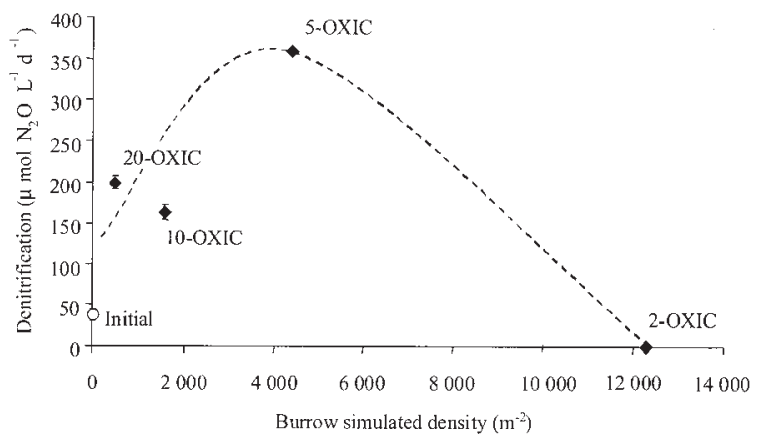

Figure 6. Denitrification rate (mean values \pm minima and maxima) in the different sediment plugs expressed as a function of the simulated burrow density. The illustrative calculation of the burrow density as a function of the plug thickness $(L)$ was made using an arbitrary internal burrow radius of $5 \mathrm{~mm}$. Dotted curve represents interpretive pattern.

$$
\begin{gathered}
N_{o w}(t)=C_{o w}(t) V_{o w} \\
N_{p w}(t)=C_{p w}(t)(1+K) V_{p w}
\end{gathered}
$$

Where: $N_{o W}(t)=$ moles of DIN in overlying water at time $t$

$N_{p W}(t)=$ moles of DIN in pore water or reversibly adsorbed at time $t$

$C_{\text {oW }}(t)=$ concentration of DIN in overlying water at time $t$

$C_{p w}(t)=$ concentration of DIN in pore water at time $t$

$V_{o w}=$ volume of overlying water (15.4 l)

$V_{p w}=$ volume of pore water

The concentrations of DIN were summed over $\mathrm{NH}_{4}^{+}, \mathrm{NO}_{2}^{-}$, and $\mathrm{NO}_{3}^{-}$measured in overlying water (Fig. 3) and in plugs (averages used; Fig. 5) at the beginning and end of the experiment. Ammonium pore water concentrations were multiplied by the factor $(1+K)$, where $K=$ reversible adsorption coefficient (dimensionless) to account for adsorption equilibrium with sediment particles. The volume of pore water for each plug set was estimated from the total plug surface exposed $\left(224 \mathrm{~cm}^{2}\right)$ in each microcosm, plug set thickness, and measured sediment porosity (porosity, $\varphi=0.774$, assuming particle density of $\left.2.6 \mathrm{~g} \mathrm{~cm}^{-3}\right)$. The ammonium adsorption coefficient is $K^{*}=1.21 \mathrm{~cm}^{3} \mathrm{~g}^{-1}\left(\mathrm{NH}_{4}^{+}\right.$ displacement by $2 \mathrm{~N} \mathrm{KCl}$ ) for the experimental sediment, giving a $K=0.91$ (Green et al., 1998). The resulting minimum net $\mathrm{N}$ production estimates relative to pore water volume are: $616,79,47$, and $7.3 \mu \mathrm{M} \mathrm{d}^{-1}$ for $2 \mathrm{~mm}, 5 \mathrm{~mm}, 10 \mathrm{~mm}$, and $20 \mathrm{~mm}$ thick plugs respectively when averaged over the course of the experiment.

\section{f. Diffusive flux estimates of reaction rates}

Minimum estimates of diffusive fluxes, $J_{\text {diff, }}$, of $\mathrm{NO}_{3}^{-}$within sediment plugs and between sediment and overlying water can be made using Fick's first law (Berner, 1980):

$$
J_{\text {diff }}=-\varphi D_{s}(\partial C / \partial z) .
$$



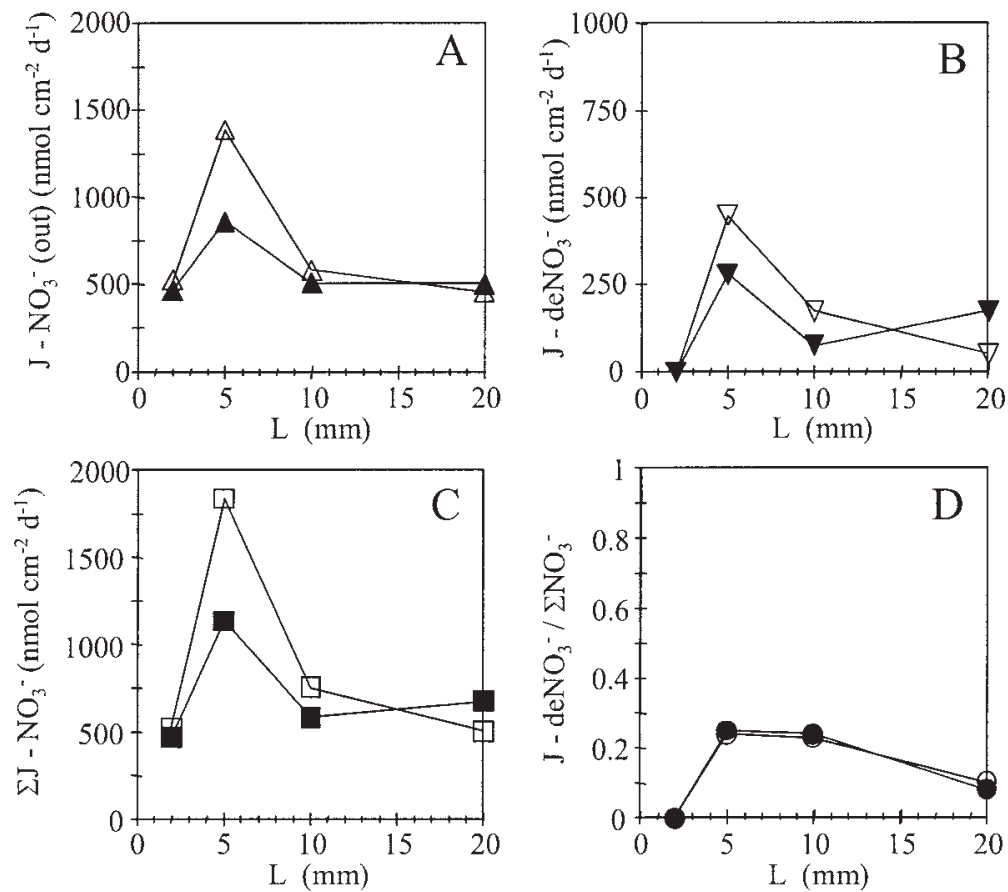

Figure 7. Comparison of $\mathrm{NO}_{3}^{-}$and denitrification flux estimates as a function of plug thickness, using either linear gradient approximations (solid symbols) to measured concentrations between sample intervals or a diffusion reaction model (open symbols) having a zone of constant nitrification overlying a denitrification zone (Eq. 3, text, Figure 8). (A) Flux of $\mathrm{NO}_{3}^{-}$into overlying water as function of plug thickness. (B) Flux of $\mathrm{NO}_{3}^{-}$into underlying sediment (denitrification). (C) Total sedimentary nitrification flux (total $\mathrm{NO}_{3}^{-}$production). (D) Ratio of denitrification to total nitrification. In all cases optimal (maximum) rates and maximum relative denitrification occurs in the $5 \mathrm{~mm}$ plug.

Flux estimates were obtained by assuming linear concentration gradients between adjacent sampling intervals and by assigning measured concentrations to the mid-point of sample intervals or to the sediment surface in the case of overlying water (assuming no significant diffusive boundary layers). The whole sediment diffusion coefficient for $\mathrm{NO}_{3}^{-}$was estimated from the free solution value, $D_{o}$, corrected for temperature $\left(T=22^{\circ} \mathrm{C}\right)$, salinity, and tortuosity using the Archie-type relation: $D_{s} \sim \varphi^{2} D_{o}$ (Li and Gregory, 1974; Ullman and Aller, 1982; Boudreau, 1997). Total nitrification fluxes were calculated from the sum of the upward and downward diffusive fluxes supported by sedimentary $\mathrm{NO}_{3}^{-}$gradients. Denitrification was defined from this standpoint as the total flux of $\mathrm{NO}_{3}^{-}$into sediment. The $5 \mathrm{~mm}$ plug had the highest net nitrification fluxes, the highest denitrification flux, and the highest ratio of denitrification to total nitrification (Fig. 7). The thin plug (2 $\mathrm{mm}$ ) supported net $\mathrm{NO}_{3}^{-}$fluxes comparable to the thickest sediment layers despite substantially lower volume of reacting material. Increased total net DIN remineralization as sediment thickness decreases is consistent with the DIN mass balance calculations made previously. 
Table 2. Model flux values: linear gradient and constant nitrification rate estimates*.

$\begin{array}{lcccc}\begin{array}{c}\text { Plug thickness, } \\ L_{2}(\mathrm{~mm})\end{array} & \begin{array}{c}\text { Nitrification } \\ \text { zone thickness, } \\ L_{1}(\mathrm{~mm})\end{array} & \begin{array}{c}\text { Denitrification } \\ \text { rate constant, } k_{d} \\ \left(\mathrm{~d}^{-1}\right)\end{array} & \begin{array}{c}\sum \mathrm{NO}_{3}^{-} \mathrm{flux}^{* *} \\ \left(\mu \mathrm{mol} \mathrm{cm}^{-2} \mathrm{~d}^{-1}\right)\end{array} & \begin{array}{c}\text { Denitrification } \\ \text { flux } \\ \left(\mu \mathrm{mol} \mathrm{cm} \mathrm{cm}^{-1}\right)\end{array} \\ 2 \text { (gradient) } & & & 0.47 & 0 \\ 2 & 2 & 0 & 0.53 & 0 \\ 5 \text { (gradient) } & 1 & 60.4 & 1.14 & 0.28 \\ 5 & & & 1.84 & 0.45 \\ 10 \text { (gradient) } & 2 & 10.1 & 0.58 & 0.077 \\ 10 & & & 0.75 & 0.17 \\ 20 \text { (gradient) } & 1 & 1.7 & 0.68 & 0.17 \\ 20 & & & 0.50 & 0.052\end{array}$

*Model equation 3.

$* *$ Sum of upward and downward flux of $\mathrm{NO}_{3}^{-}$from production zone.

\section{g. Diffusion reaction models-average reaction rates}

Estimates of the average reaction rates over specific intervals of plug sediments were also obtained from a simple two zone transport-reaction model evaluated at steady state (Vanderborght and Billen, 1975; Billen, 1982; Jahnke et al., 1982). The small thicknesses of the plugs, the $\mathrm{N}$-compound concentration patterns in the overlying water, and sampling time should have ensured that distributions in the plugs were at a pseudo-steady state (see subsequent section). In each plug set, it was assumed that an upper zone of net nitrification overlaid a zone of net denitrification. Nitrification rate was approximated as constant over the oxygenated interval depth $L_{1}$, and denitrification was taken as a first order reaction with respect to $\mathrm{NO}_{3}^{-}$concentration. The model equations and boundary conditions are:

$$
\begin{gathered}
\text { Zone } 1 \text { (nitrification) }\left(0 \leq z \leq L_{1}\right): D_{s}\left(\partial^{2} C_{1} / \partial Z\right)+R_{N O}=0 \\
\text { Zone } 2 \text { (denitrification) }\left(L_{1} \leq z \leq L\right): D_{s}\left(\partial^{2} C_{2} / \partial Z^{2}\right)-k_{d N} C_{2}=0 \\
\text { Boundary conditions: } z=0, C_{1}=C_{T} ; z=L, \partial C_{2} / \partial z=0 \\
z Z=L_{1}, C_{1}=C_{2}, \partial C_{1} / \partial z=\partial C_{2} / \partial Z
\end{gathered}
$$

The value of $L_{1}$ for each plug group was set equal to the base of the sample interval in which the maximum $\mathrm{NO}_{3}^{-}$concentration was measured. We found that if the entire measured penetration depth of $\mathrm{O}_{2}$ was used (see subsequent discussion), it was not possible to obtain even moderately accurate fits to the $\mathrm{NO}_{3}^{-}$distributions if a constant nitrification rate were also used. The analytical solution $C(z)$ to Eqs. 3a-c was integrated (averaged) over the finite intervals $0-1 \mathrm{~mm}, 1-2 \mathrm{~mm}$, and $2-L$ corresponding to the sampling depths. Optimal values of $R_{N O}$ (zeroth order nitrification rate) and $k_{d N}$ (denitrification rate constant) were then estimated from simultaneous best fits of the integral solutions to the average $\mathrm{NO}_{3}^{-}$values using the Levenberg-Marquardt method (Table 2; Fig. 8). The nitrification and denitrification fluxes so obtained were consistently higher than those 


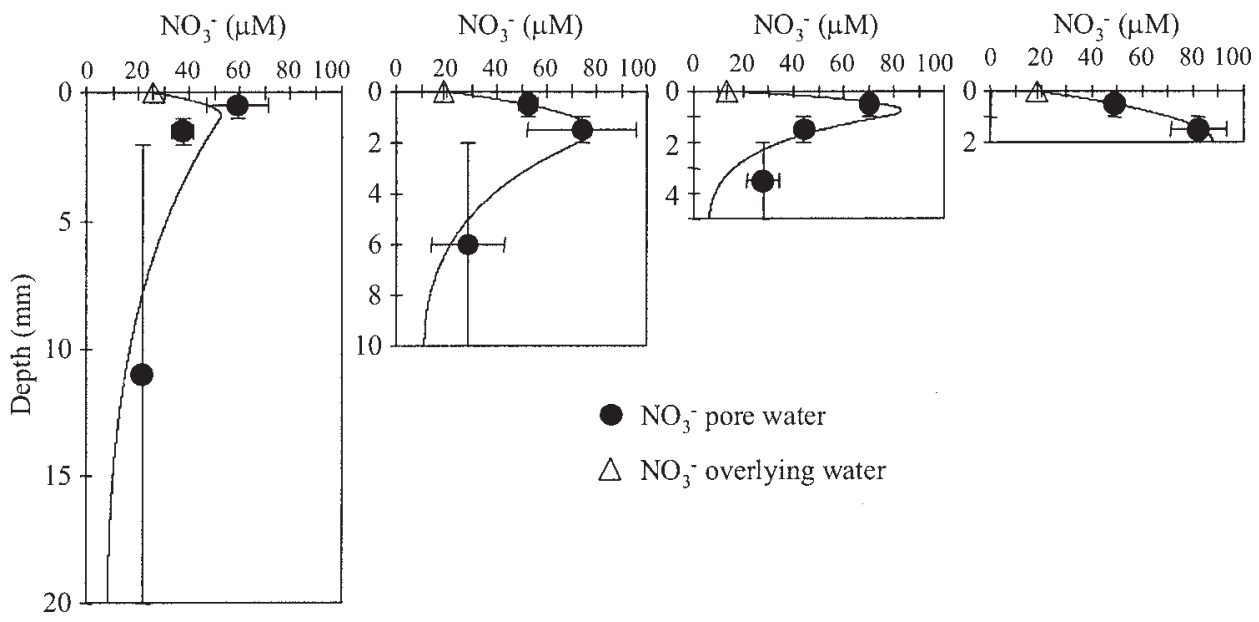

Figure 8. $\mathrm{NO}_{3}^{-}$pore water profiles in plugs (from Figure 5; mean $\pm \mathrm{SD}$ ), overlying water is plotted as an open triangle. The continuous curves represent diffusion reaction model fits using equation 3 (surface zone of constant nitrification rate over interval $L_{1}$, first order denitrification in underlying zone).

derived from the simple linear gradient approximations using equation (2), but clearly showed the same relative reaction rate patterns (Fig. 7), that is, maximum rates and optimal (e.g., maximum ratio of denitrification/nitrification) coupling between oxic and anoxic zones in the $5 \mathrm{~mm}$ plugs. The whole sediment $\mathrm{NO}_{3}^{-}$diffusion coefficient in each case was estimated as described previously.

\section{h. Coupled models and kinetics of nitrification/denitrification}

The distribution patterns of $\mathrm{O}_{2}, \mathrm{NO}_{3}^{-}$, and $\mathrm{NH}_{4}^{+}$were further examined using more sophisticated coupled transient and steady state diffusion-reaction models in order to evaluate the assumptions of steady state, different possible concentration dependent forms for nitrification reaction kinetics, and most importantly in the present cases, the scaledependent reaction balances during the experiment. For example, one characteristic of the $\mathrm{NO}_{3}^{-}$(and $\mathrm{NO}_{2}^{-}$) profiles that cannot be reproduced well by a constant, average nitrification rate as used above, is the near surface $(0-1 \mathrm{~mm})$ maximum found in the 5 and $20 \mathrm{~mm}$ plugs (Figs. 5, 6). Three different kinetic functions for nitrification, $R_{\mathrm{NO} 3}$, were considered here:

$$
\begin{gathered}
R_{\mathrm{NO} 3}=v_{\mathrm{NO} 3}\left(\mathrm{O}_{2}\right)\left(\mathrm{NH}_{4}^{+}\right) /\left[\left(\left(\mathrm{O}_{2}\right)+K_{\mathrm{O} 2, \mathrm{NO} 3}\right)\left(\left(\mathrm{NH}_{4}^{+}\right)+K_{\mathrm{NH} 4, \mathrm{NO} 3}\right)\right] \\
R_{\mathrm{NO} 3}=k_{\mathrm{NO} 3}\left(\mathrm{O}_{2}\right)\left(\mathrm{NH}_{4}^{+}\right) \\
R_{\mathrm{NO} 3}=k_{\mathrm{NO} 3}^{*}\left(\mathrm{O}_{2}\right)^{2}\left(\mathrm{NH}_{4}^{+}\right)
\end{gathered}
$$

The hyperbolic kinetic Eq. (4a) is based on the experimentally measured responses of pure cultures of ammonia oxidizing and nitrifying bacteria to varying concentrations of $\mathrm{O}_{2}$ and $\mathrm{NH}_{4}^{+}$(Brion and Billen, 1998) $\left(\mathrm{NH}_{4}^{+}\right.$represents total dissolved ammonia species in all 
cases). The constants $v_{\mathrm{NO} 3}, K_{\mathrm{O} 2, \mathrm{NO} 3}$, and $K_{\mathrm{NH} 4, \mathrm{NO} 3}$ correspond to maximum reaction rate and half saturation constants for $\mathrm{O}_{2}$ and $\mathrm{NH}_{4}^{+}$respectively. Maximum reaction, $V_{\mathrm{NO} 3}$, depends directly on local biomass (Brion and Billen, 1998). The second order kinetic form with fixed rate constant $k_{\mathrm{NO}}$, Eq. (4b), was successfully employed by Van Cappellen and Wang (1996) as a likely approximation for overall nitrification kinetics in surface sediments. Eq. (4c) was also utilized here as a possible phenomenological alternative consistent with overall reaction stoichiometry but without a previous observational basis.

The overall model formulation follows the hyperbolic oxidant consumption and serial inhibition approach of Rabouille and Gaillard (1991) and Van Cappellen et al. (1993), so that for the dissolved species set $(i),\left(i=\mathrm{O}_{2}, \mathrm{NO}_{3}^{-}, \mathrm{NH}_{4}^{+}\right)$:

$$
\left(1+K_{i}\right) \partial(i) / \partial t=D_{s, i}\left(\partial^{2}(i) / \partial z^{2}\right)+\Sigma R_{i}
$$

with:

$$
\begin{aligned}
\Sigma R_{\mathrm{O} 2} & =-\sigma_{\mathrm{O} 2 V_{C}}\left(\mathrm{O}_{2}\right) /\left(K_{\mathrm{C}, \mathrm{O} 2}+\left(\mathrm{O}_{2}\right)\right)-R_{\mathrm{NO} 3} \\
\Sigma R_{\mathrm{NO} 3} & =R_{\mathrm{NO} 3}-\sigma_{\mathrm{NO}_{C} V_{C}}\left(\mathrm{NO}_{3}\right)\left(\mathrm{Inhibit}_{\mathrm{O} 2, \mathrm{NO} 3}\right) /\left(K_{\mathrm{C}, \mathrm{NO} 3}+\left(\mathrm{NO}_{3}\right)\right) \\
\Sigma R_{\mathrm{NH} 4} & =\sigma_{\mathrm{NH}} V_{C}-R_{\mathrm{NO} 3} \\
V_{C} & =\text { maximum organic } \mathrm{C} \text { oxidation rate } \\
\sigma_{\mathrm{O} 2}, \sigma_{\mathrm{NO}}, \sigma_{\mathrm{NH}} & =\text { stoichiometric reaction ratios } \mathrm{O}_{2} / \mathrm{C}, \mathrm{NO}_{3} / \mathrm{C}, \text { and } \mathrm{NH}_{4}^{+} / \mathrm{C} \\
\mathrm{Inhibit}_{\mathrm{O} 2, \mathrm{NO} 3} & =K_{\mathrm{I}, \mathrm{O} 2, \mathrm{NO} 3} /\left(K_{\mathrm{I}, \mathrm{O} 2, \mathrm{NO} 3}+\left(\mathrm{O}_{2}\right)\right) \\
K_{\mathrm{I}, \mathrm{O} 2-\mathrm{NO} 3} & =\text { inhibition constant for } \mathrm{O}_{2} \text { on denitrification } \\
K_{i} & =\text { reversible adsorption coefficient }\left(=0 \text { for } \mathrm{O}_{2}, \mathrm{NO}_{3}^{-}\right)
\end{aligned}
$$

Qualitatively, this set of coupled equations accounts for diffusive transport, the uptake of $\mathrm{O}_{2}$ by aerobic respiration and nitrification, the uptake and production of $\mathrm{NO}_{3}^{-}$by denitrification and nitrification, and the production and consumption of $\mathrm{NH}_{4}^{+}$during ammonification and nitrification. The inhibition of denitrification by aerobic activity was incorporated in the inhibition function, Inhibit ${ }_{\mathrm{O} 2-\mathrm{NO} 3}$, with $K_{I, \mathrm{O} 2-\mathrm{NO} 3}=1 \mu \mathrm{M}$ as an approximation (Humphrey, 1972; Boudreau, 1997). The equation set was evaluated using a fully explicit finite difference routine for the initial and boundary conditions:

$$
\begin{gathered}
t=0,0 \leq z \leq L,(i)=(i)_{0} ; t>0, z=0,(i)=(i)_{T} \\
z=L, \partial(i) / \partial z=0
\end{gathered}
$$

Numerical solutions were stable and mass balances maintained over the range of evaluation. Whole sediment diffusion coefficients were estimated in each case from the free solution values at $22^{\circ} \mathrm{C}$ assuming the Archie-type relation given previously.

Examples of steady state distributions of $\mathrm{O}_{2}, \mathrm{NO}_{3}$, and $\mathrm{NH}_{4}^{+}$for a $5 \mathrm{~mm}$ plug are shown in Figure 9. In all cases, model examples assume: $v_{c}=3.5 \mathrm{mM} \mathrm{d}^{-1} ; \sigma_{\mathrm{O} 2}, \sigma_{\mathrm{NO}}, \sigma_{\mathrm{NH}}=1$, 0.8 , and $0.2 ; K_{\mathrm{C}, \mathrm{O} 2}=10 \mu \mathrm{M} ; K_{C, \mathrm{NO} 3}=10 \mu \mathrm{M}$; and a reversible adsorption constant $K_{\mathrm{NH} 4}=0.91$ (Green et al., 1998). Overlying water concentrations were fixed at 240, 13.5, and $0 \mu \mathrm{M}$ for $\mathrm{O}_{2}, \mathrm{NO}_{3}$, and $\mathrm{NH}_{4}^{+}$respectively. Model I assumes nitrification kinetics $\left(R_{\mathrm{NO} 3}\right.$, Eq. 4 a) with $v_{\mathrm{NO} 3}=50 \mathrm{mM} \mathrm{d}^{-1} ; K_{\mathrm{O} 2, \mathrm{NO} 3}=20 \mu \mathrm{M} ; K_{\mathrm{NH} 4, \mathrm{NO} 3}=100 \mu \mathrm{M}$ (half 

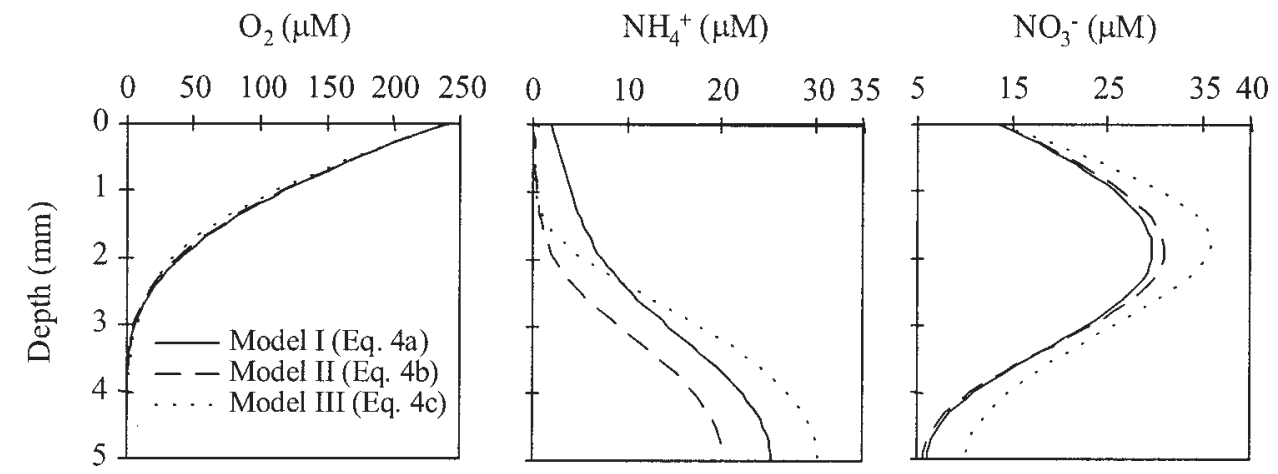

Figure 9. Example steady state model profiles of $\mathrm{O}_{2}, \mathrm{NH}_{4}^{+}$, and $\mathrm{NO}_{3}^{-}$for the 3 nitrification kinetic functions outlined in text. The subsurface $\mathrm{NO}_{3}^{-}$maximum cannot occur in the surface $0-1 \mathrm{~mm}$ interval without major changes in kinetic parameters, additional reactions not accounted for, or relative rates of remineralization (e.g. increased $\mathrm{N} / \mathrm{C}$ ratio).

saturation constants after Brion and Billen, 1998). Model II assumes overall second order kinetics $\left(R_{\mathrm{NO} 3}\right.$, Eq. $\left.4 \mathrm{~b}\right)$ with $k_{\mathrm{NO} 3}=30 \mu \mathrm{M}^{-1} \mathrm{~d}^{-1}$. Model III assumes nitrification kinetics second order in $\mathrm{O}_{2}$ and first order in $\mathrm{NH}_{4}^{+}\left(R_{\mathrm{NO} 3}\right.$, Eq. $\left.4 \mathrm{c}\right)$, with $k_{\mathrm{NO} 3}^{*}=$ $0.5 \mu \mathrm{M}^{-2} \mathrm{~d}^{-1}$. These values were chosen to produce simultaneous approximations to the profiles primarily for purposes of illustration of basic principles and relative behavior rather than for optimal fits to individual data sets.

Steady state (pseudo) was achieved in $\sim 0.2(L=2 \mathrm{~mm})$ to $\sim 4$ days $(L=20 \mathrm{~mm})$ for a wide range of potential reaction rates that were broadly constrained by observed concentration distributions. The use of a constant overlying water boundary condition in model calculations is therefore a good approximation given the slow rate of change in water properties over the last several days of the experiment (Fig. 3). A primary conclusion of these calculations is that it was not possible to simulate $\mathrm{NO}_{3}^{-}$maxima in the upper $0-1 \mathrm{~mm}$ of plugs with any combination of reaction rates using forms of Eq. (4) that were simultaneously consistent with $\mathrm{O}_{2}, \mathrm{NO}_{3}^{-}$, and $\mathrm{NH}_{4}^{+}$distributions (and $\mathrm{HCO}_{3}^{-}$distributions, Aller et al., in preparation) and with the magnitude of observed fluxes. The $\mathrm{NO}_{3}^{-}$ distributions require a far higher nitrification rate at the sediment-water interface and also require maximum nitrification to occur at a much higher average $\mathrm{O}_{2}$ than can be accounted for by the assumed kinetic functions. These results are consistent with the need to restrict nitrification in the model Eq. (3) to intervals less than the penetration depth of $\mathrm{O}_{2}$.

The model calculations (Eq. 4) using a fixed overall ammonification rate $\left(\sigma_{\mathrm{NH} V_{\mathrm{C}}}\right)$ in all cases demonstrate that the relative rates of nitrification/ammonium production, denitrification/nitrification, denitrification/ammonium production, and nitrification/total oxygen flux should vary regularly with plug thickness at steady state regardless of the assumed kinetics of nitrification (Fig. 10). Because the overall ammonification rate is constant (volumetric), the steady flux of $\mathrm{NH}_{4}^{+}$into the oxic zone increases linearly with plug thickness. The proportion of the oxygen flux utilized by nitrification increases, and the oxygen penetration 

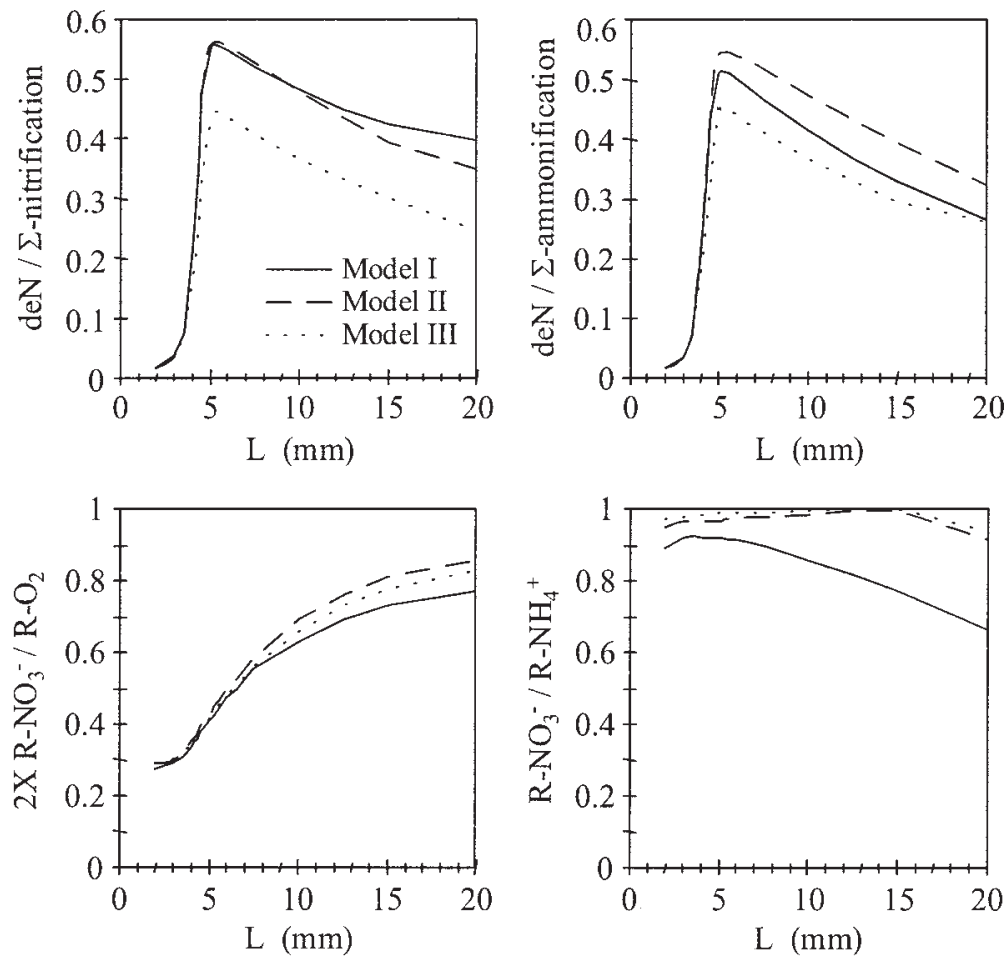

Figure 10. Model calculations demonstrating steady state reaction balances as a function of both diffusion scale and three different nitrification kinetic functions (Eqs. 4a.b.c) in planar geometries comparable to the experimental sediment plugs. The maximum $\mathrm{C}_{\text {org }}$ remineralization rate is fixed at $3.5 \mathrm{mM} \mathrm{d}^{-1}$ and the N/C ammonification ratio at 0.2 (see text). Model I assumes hyperbolic nitrification kinetics (Eq. 4a), Model II first order kinetics in both $\mathrm{O}_{2}$ and $\mathrm{NH}_{4}^{+}$, and Model III second order in $\mathrm{O}_{2}$, first order in $\mathrm{NH}_{4}^{+}$(see text). Maximum denitrification relative to nitrification and ammonification occurs between $5-6 \mathrm{~mm}$ scaling. Note the proportion of the $\mathrm{O}_{2}$ flux utilized for other than $\mathrm{C}_{\text {org }}$ oxidation increases steadily with sediment thickness and becomes progressively dominated by reoxidation of anaerobic metabolites.

depth decreases, as the flux into the oxic zone of reduced metabolites (solely $\mathrm{NH}_{4}^{+}$in these model considerations) from the anoxic zone, increases with sediment thickness (Figs. 10, 11). Total nitrification fluxes increase directly with plug thickness (results not shown), eventually reaching a maximum determined by the maximum supply of $\mathrm{O}_{2}$, the specific nitrification kinetics, and competition with additional reductants entering the oxic zone. The planar models predict that about $\sim 30-50 \%$ of the remineralized $N$ should be denitrified, depending on the exact reaction kinetics and relative scaling of the redox zones. Optimal couplings between nitrification, denitrification, and ammonification (highest denitrification/nitrification; highest denitrification/ammonification) are achieved at sediment scales between $5-10 \mathrm{~mm}$ for the general remineralization rates in the experimental sediment. 


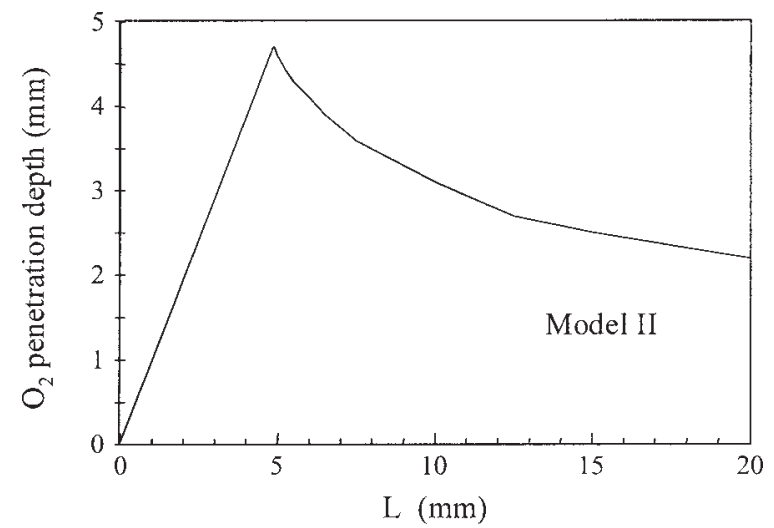

Figure 11. Example $\mathrm{O}_{2}$ penetration depth $(\geq 0.1 \mu \mathrm{M}$ concentration depth) predicted by Model 2 nitrification kinetics (Eq. $4 \mathrm{~b}, 1^{\circ} \mathrm{O}_{2}, 1^{\circ} \mathrm{NH}_{4}^{+}$) as a function of sediment thickness (Model values as in Fig. 8, 9 and text). If higher levels of $\mathrm{O}_{2}$ concentration are used to define penetration depth (e.g. $\geq 10 \mu \mathrm{M}$ ), similar relative patterns are obtained but the linear portion is contracted and maximum penetration depth occurs at a smaller $L$.

\section{Discussion}

Our experimental and model results demonstrate that small changes in the thicknesses of adjacent oxic-anoxic zones result in significant differences in both the absolute and relative rates of nitrification and denitrification in sediments. The scale-dependent changes in redox reactions in our experimental sediment plugs presumably mimic to various extents those attained in portions of bioturbated deposits as any two oxygenated burrow centers move closer (thin plugs) or farther apart (thick plugs) (Fig. 1). It is, therefore, clear that nitrification-denitrification interactions in the bioturbated zone are a function of burrow spacing, size (radii), and nearest neighbor diffusive interactions in addition to local sediment properties determined by species-specific activities (Fig. 4).

\section{a. Nitrification}

The primary source of $\mathrm{NO}_{3}^{-}$for sedimentary denitrification is normally $\mathrm{NO}_{3}^{-}$formed within the oxic sediment zone adjacent to the oxygenated water boundary (Billen, 1982). The rate of $\mathrm{NO}_{3}^{-}$formation depends on the diffusive supply of $\mathrm{O}_{2}$ and $\mathrm{NH}_{4}^{+}$, nitrification kinetics (including specific properties of bacterial populations), and competition between various reductants (e.g. $\mathrm{C}_{\text {org }}, \mathrm{DOC}, \mathrm{NH}_{4}^{+}, \mathrm{H}_{2} \mathrm{~S}, \mathrm{Fe}^{++}, \mathrm{Mn}^{++}$) for $\mathrm{O}_{2}$. The diffusive flux of $\mathrm{NH}_{4}^{+}$increases linearly with plug thickness whereas the $\mathrm{O}_{2}$ flux reaches a maximum value limited by overlying water concentration and diffusive transport (Jørgensen, 2001). Nitrification rates should therefore increase with plug thickness (burrow spacing) and likely plateau (saturate) or begin to decrease, depending on the exact competitive relations of $\mathrm{NH}_{4}^{+}$with additional reductants supplied to the oxic zone. Overall, nitrification should consume a progressively greater proportion of the $\mathrm{O}_{2}$ flux as anoxic zone thickness increases (Fig. 10). 
The experimental results show a distinct maximum in nitrification rates in the $5 \mathrm{~mm}$ plugs compared to thinner $(2 \mathrm{~mm})$ or thicker plugs $(10,20 \mathrm{~mm})$ (Fig. 7$)$. Whereas the increase of nitrification rate in the $5 \mathrm{~mm}$ plug relative to the thinner $2 \mathrm{~mm}$ plug is expected from the increased $\mathrm{NH}_{4}^{+}$flux from the anoxic zone, the large decrease of nitrification rate in plugs with larger ratios of anoxic/oxic zone thicknesses (i.e. the 10 and $20 \mathrm{~mm}$ plugs) must reflect: (1) higher fluxes of $\mathrm{NH}_{4}^{+}$into the oxic zone of the $5 \mathrm{~mm}$ plug relative to thicker plugs; and/or, (2) increased fluxes of competing reductants into the oxic zone of the thicker plugs.

There is strong previous experimental evidence that increased transport efficiency of solutes and decreased metabolite build-up affect net remineralization rates in sediments. In completely anoxic sediment, net remineralization rate, as measured by $\mathrm{NH}_{4}^{+}$release, increases as diffusive scale (plug thickness) and metabolite buildup decrease (Aller and Aller, 1998). Our present results are consistent with those findings in that the maximum in nitrification rate in the $5 \mathrm{~mm}$ plugs suggests an enhanced net flux of $\mathrm{NH}_{4}^{+}$into the oxic zone relative to thicker plugs despite the greater potential source in the latter. As noted earlier (Eq. 1), the release of inorganic $\mathrm{N}$ from plugs into the overlying water reservoirs also indicate increased net remineralization of $\mathrm{N}$ as plug thickness decreased. Thus, at least a portion of the maximum nitrification rate observed at the intermediate plug scale length $(5 \mathrm{~mm})$ may reflect an optimal balance between diffusive supply of $\mathrm{O}_{2}$ and an enhancement of net ammonification rate in the anoxic zone as overall diffusive scale decreases.

Regardless of whether the net remineralization rate (volumetric) is a function of transport scale, the steady flux of reduced solutes into the oxic zone must eventually increase as total anoxic zone thickness increases (integration of the volumetric rate with depth). As a result, the oxic zone becomes thinner as overall plug thickness increases, and the region within which aerobic nitrification can occur contracts (Figs. 4, 11). This contraction of the oxic zone must accentuate competition between possible reductants for $\mathrm{O}_{2}$ and may further contribute to the decrease in net nitrification as the ratio of anoxic/oxic zone volumes increases.

The measured $\mathrm{NO}_{3}^{-}$distributions are consistent with the concept that competition between reductants can be an important influence on sedimentary nitrification. We observed the maximum net nitrification in regions of relatively high $\mathrm{O}_{2}$ near the sedimentwater interface (Figs. 4, 5) and not at the redoxcline where $\mathrm{O}_{2}$ is low and $\mathrm{NH}_{4}^{+}$high. These observations have been confirmed by additional, very detailed transient state experiments similar in design to the present experiments (Eriksson and Aller, 2001). The shift of the highest $\mathrm{NO}_{3}^{-}$concentrations toward the sediment-water interface (first sample interval) could not be reproduced by any of the nitrification or remineralization model kinetic functions (Eqs. 3, 4) used here, when distributions were also constrained by the $\mathrm{O}_{2}$ penetration depth and $\mathrm{NH}_{4}^{+}$profiles (i.e. remineralization rate). Model fits using a simple constant nitrification rate (Eq. 3; Fig. 8) are not accurate unless $\mathrm{O}_{2}$ penetration depths (i.e. nitrification zone) are restricted to intervals $<0.5 \times$ the actual value, for example $1 \mathrm{~mm}$ rather than $3 \mathrm{~mm}$ (Fig. 8; plug $5 \mathrm{~mm}$ ). These findings suggest that, for example, the $\mathrm{O}_{2}$ half saturation constant (Eq. 4a) derived from laboratory studies of pure cultures (Brion and 
Billen, 1998) is actually far higher (e.g. $>100 \mu \mathrm{M}$ compared to $\sim 10-20 \mu \mathrm{M}$ ) in natural sediments with mixed populations and competing reactions. It was for this reason that a second order kinetic dependence on $\mathrm{O}_{2}$ concentration (Eq. 4c), which shifts maximum nitrification rates toward higher $\mathrm{O}_{2}$, was also utilized as a possible kinetic form in our calculations. The functional ecological effect of a shift of nitrification to higher $\mathrm{O}_{2}$ is to decrease reaction competition with other reductants produced during anaerobic metabolism.

Our data and models show that for a variety of reasons, sedimentary nitrification is a strong function of both the absolute and relative scaling of adjacent oxic and anoxic zones. A maximum rate of nitrification is achieved under particular spatial scales that allow for optimal balances between $\mathrm{O}_{2}$ flux, $\mathrm{NH}_{4}^{+}$production rates in adjacent oxic/anoxic zones, and the fluxes of competitive metabolites into the oxic zone. These optimal nitrification conditions were found in the present case for diffusive transport scales typically observed in the bioirrigated zone, equivalent to $\sim 1 \mathrm{~cm}$ between oxygenated boundaries (or $\sim 5 \mathrm{~mm}$ half-distance between burrows).

\section{b. Coupled nitrification-denitrification}

As in the case of nitrification, a number of factors determine the rate of denitrification and the coupling of reactions between oxic and anoxic zones. Coupling between zones consists of the flux of $\mathrm{NH}_{4}^{+}$and reduced metabolites from the anoxic into the oxic zone, and the return flux of $\mathrm{NO}_{3}^{-}$from the oxic into the denitrification zone. The distance between the oxygenated overlying water boundary (irrigated burrow center) and the reflective boundary at the base of the plugs (approximately midway between irrigated burrow centers) controls the overall transport scale and the relative abundances of oxidants $\left(\mathrm{O}_{2}, \mathrm{NO}_{3}^{-}\right)$and reductants $\left(\mathrm{NH}_{4}^{+}\right)$. Given the remineralization rates in the experimental sediment, the sediment became fully oxygenated and denitrification was hindered by $\mathrm{O}_{2}$ for sediment thicknesses $<5 \mathrm{~mm}$ (e.g., Payne, 1976; Kapralek et al., 1982) (Figs. 4, 6, 11). As sediment thickness increased to $\sim 5 \mathrm{~mm}$, nitrification increased to a maximum for the reasons discussed previously. Denitrification varied in direct proportion to nitrification, also reaching an optimum (maximum) rate in the $5 \mathrm{~mm}$ thick plug (Fig. 6).

Regardless of whether net remineralization rates $\left(\mathrm{NH}_{4}^{+}\right.$production) increase with a decrease in overall diffusive transport scale, changes in the relative rates and coupling of reactions between zones must occur. Model calculations demonstrate that the proportion of denitrification/nitrification and denitrification/ammonification in plugs first reach maxima and then decrease as anoxic zone thicknesses increase (Fig. 10). Nitrification consumes a progressively larger proportion of the $\mathrm{O}_{2}$ flux as overall sediment thickness increases, but a larger proportion of total $\mathrm{NH}_{4}^{+}$production (flux) escapes as nitrification kinetics in the oxic zone become saturated (Fig. 10). The decrease in denitrification with increasing plug thickness $>5 \mathrm{~mm}$ also reflects the fact that a greater proportion of the $\mathrm{NO}_{3}^{-}$formed is lost into the overlying water as the oxic zone contracts and the $\mathrm{NO}_{3}^{-}$maximum moves closer to the sediment-water interface. For the present illustrative calculations, we assumed that reaction kinetic parameters such as reaction rate constants (e.g. $k_{\mathrm{NO} 3}$, Eq. $4 \mathrm{~b}$ ) do not 
change with overall scale (i.e. are not a function of metabolite inhibition of net remineralization, competition between reductants for $\mathrm{O}_{2}$, etc.). The dependence of reaction balances on diffusion scale are even more accentuated if net remineralization rate (volumetric) varies inversely with thickness and competition between reductants for $\mathrm{O}_{2}$ are considered.

Therefore at a given remineralization (ammonification) rate there are particular scales of oxic and anoxic zones that produce maximum rates of reactions and maximum efficiency of reaction coupling between zones (e.g., maximum denitrification/nitrification, maximum denitrification/ammonification). In the case of denitrification, for example, the penetration of $\mathrm{NO}_{3}^{-}$into underlying sediment becomes a progressively smaller proportion of the total anoxic region as plug thickness increases. The simultaneous contraction of the nitrification zone with plug thickness accentuates this proportional decrease. If denitrification is assumed to be a first order reaction in $\mathrm{NO}_{3}^{-}$, (Eq. 3b), the lengthscale of $\mathrm{NO}_{3}^{-}$penetration into the anoxic zone is $\sim \sqrt{D_{s} / k_{d N}}$. Thus, increasing the thickness of the anoxic zone beyond that scale does not optimally couple ammonification and nitrification to increased denitrification.

\section{c. Extrapolation to the bioirrigated zone and natural conditions}

For the experimental sediment used here, maximum rates and optimal coupling between aerobic and anaerobic reactions occurred in planar geometries for sediment thicknesses of $\sim 5 \mathrm{~mm}$. This overall scale would correspond roughly to evenly spaced burrow structure abundances of $\sim 3000-11,000 \mathrm{~m}^{-2}$, depending on the radius of the oxygenated burrows involved (e.g., $r=0.05-0.5 \mathrm{~cm}$ ). For smaller and larger thicknesses (diffusive lengthscales), a combination of factors decreased the overall efficiency of coupling between zones. The exact scaling of interactions between reactions in adjacent oxic and anoxic zones is affected by radial geometries, such as typically characterize the regions around irrigated burrows, and can only be approximately simulated by planar geometries (Aller, 1988, 2001; Fig. 1). In addition, the effective scaling between oxygenated burrow microenvironments is also determined by various aspects of burrowing behavior, including burrow generation rates, burrow longevity, and irrigation frequency (burrow lumen boundary conditions). For example, active burrowers or tube-builders can produce enhanced effects at lower population densities than sedentary species (Woodin and Marinelli, 1991). Even for sedentary species, burrow size, orientation, and spacing are commonly highly variable locally and change with time. Statistical distributions of community burrow patterns in space and time are therefore most properly considered in quantitative models of average transport-reaction geometries (Gilbert et al., 1995; Furukowa et al., 2001; Koretsky et al., 2002).

There are also other, theoretically possible, sedimentary nitrification and $\mathrm{NO}_{3}^{-}$reduction reactions which may be affected by biogenic transport processes and which were not included in our considerations. For example, anaerobic nitrification can apparently occur through a Mn-oxide reduction pathway in which the flux of Mn-oxide is largely determined by bioturbation (Luther et al., 1997; Hulth et al., 1999; Anschutz et al., 2000). The $\mathrm{NO}_{3}^{-}$ profiles in basal regions of plugs and their departure from the simplest model predictions in 
the present experiments hint at the occurrence of such anaerobic nitrification reactions (Fig. 7). The reduction of $\mathrm{NO}_{3}^{-}$by alternative reductants such as $\mathrm{NH}_{4}^{+}$may also occur and further complicate reaction kinetics and zonal coupling (Thamdrup and Dalsgaard, 2000).

The quantitative results derived from this study should not be directly extrapolated without additional modifications to natural bioturbated deposits. For example, speciesspecific characteristics such as mucus secretion, particle selection, bioirrigation activity patterns, and additional factors such as $\mathrm{C}_{\text {org }}$ flux to the sediment surface, are important controls on sedimentary redox reactions. Our experiments did not incorporate interstitial advection of pore water that can occur around biogenic structures in highly permeable sands (Huettel and Webster, 2001). The possible roles of meiofauna in altering reaction rates and local transport were also not explicitly examined (e.g., Reichelt et al., 1991). Our experiments and models clearly demonstrate; however, that whatever the burrowing organisms involved, the balance between stimulation/inhibition of denitrification and $\mathrm{N}$ remineralization is highly dependent on burrow or irrigated microenvironment distribution and associated diffusion-reaction structure. A greater effort to statistically document geometric relations (scaling distributions) between oxic-anoxic zones within bioturbated deposits is clearly required for quantitative interpretation and predictive modeling of sedimentary $\mathrm{N}$ cycling.

\section{Conclusions}

Irrigated burrow structures produce complex patterns of oxic-anoxic microenvironments in the bioturbated zone.

A major property determining the absolute and relative rates of sedimentary redox reactions such as nitrification-denitrification is the characteristic transport scale set by burrow lumen size and the spacing of oxygenated burrow centers.

The dependence of coupled redox reactions such as nitrification-denitrification on oxic-anoxic zonal scaling around and between burrows can be simulated in part by plugs of variable sediment thickness exposed on one surface to oxygenated water. For a given remineralization rate (reactive $\mathrm{C}_{\text {org }}$ ), an optimal scaling exists which simultaneously maximizes nitrification, denitrification, the ratio of denitrification/nitrification, and the ratio of denitrification/ammonification.

Common size and abundance ranges of infaunal communities can apparently readily achieve optimal reaction scalings for nitrification-denitrification.

The in-situ kinetics of nitrification in the oxic zone of organic rich sediments are not well constrained by presently accepted relationships, implying that natural populations of nitrifiers must be utilized in future kinetic studies of the dependence of aerobic nitrification on $\mathrm{O}_{2}, \mathrm{NH}_{4}^{+}$, and the simultaneous presence of multiple anaerobic metabolites.

Redox reaction coupling during the sedimentary cycling of $\mathrm{N}$ in the bioirrigated zone has the potential for far greater complexity than has been commonly appreciated.

Acknowledgments. We thank Mark Green for help during sediment and water sampling. Two anonymous reviewers and the Associate Editor, Donald L. Rice, provided helpful comments on an 
earlier draft of this paper. This work was supported by NSF grant OCE 9730933 to Robert C. Aller, by postdoctoral fellowships from the Swedish Natural Science Research Council and the Swedish Institute to Stefan Hulth, and postdoctoral fellowships grants from the Société de Secours des Amis des Sciences and the G.D.R. 1123 "HYCAR" to Franck Gilbert. Nereis Park contribution number 001.

\section{REFERENCES}

Aller, R. C. 1984. The importance of relict burrow structures and burrow irrigation in controlling sedimentary solute distributions. Geochim. Cosmochim. Acta, 48, 1929-1934.

1988. Benthic fauna and biogeochemical processes in marine sediments: the role of burrow structures, in Nitrogen Cycling in Coastal Environments, T. H. Blackburn and J. Sørensen, eds., John Wiley and Sons, 301-338.

2001. Transport and reactions in the bioirrigated zone, in The Benthic Boundary Layer: Transport Processes and Biogeochemistry, B. Boudreau and B. B. Jørgensen, eds., Oxford Press, 269-301.

Aller, R. C. and J. Y. Aller. 1998. The effect of biogenic irrigation intensity and solute exchange on diagenetic reaction rates in marine sediments. J. Mar. Res., 56, 905-936.

Aller, J. Y., R. C. Aller and M. A. Green. 2002. Benthic faunal assemblages and carbon supply along the continental shelf/shelf break-slope off Cape Hatteras, North Carolina. Deep Sea Res. II, 49, $4599-4625$.

Aller, R. C. and J. E. Mackin. 1989. Open-incubation, diffusion methods for measuring solute reactions rates in sediments. J. Mar. Res., 47, 411-440.

Aller, R. C., J. Y. Yingst and W. J. Ullman. 1983. Comparative biogeochemistry of water in interdidal Onuphis (Polychaeta) and Upogebia (Crustacea) burrows: temporal patterns and causes. J. Mar. Res., 41, 571-604.

Anschutz, P., B. Sundby, L. Lefrançois, G. W. Luther III and A. Mucci. 2000. Interactions between metal oxides and species of nitrogen and iodine in bioturbated marine sediments. Geochim. Cosmochim. Acta, 64, 2751-2763.

Balderston, W. L., B. Sherr and W. J. Payne. 1976. Blockage by acetylene of nitrous oxide production in Pseudomonas perfectomarinus. Appl. Environ. Microbiol., 81, 504-508.

Berelson, W. M., D. Heggie, A. Longmore, T. Kilgore, G. Nicholson and G. Skyring. 1998. Benthic nutrient recycling in Port Phillip Bay, Australia Estuar. Coast. Shelf Sci., 46, 917-934.

Berner, R. A. 1980. Early Diagenesis: A Theoretical Approach, Princeton University Press, 241 pp.

Billen, G. 1982. An idealized model of nitrogen recycling in marine sediments. Am. J. Sci., 282, $512-541$.

Boudreau, B. P. 1996. The diffusive tortuosity and porosity of fine-grained sediments. Geochim. Cosmochim. Acta, 60, 3139-3142.

1997. Diagenetic Models and Their Implementation, Springer-Verlag, 414 pp.

Boudreau, B. P. and R. L. Marinelli. 1994. A modeling study of discontinuous biological irrigation. J. Mar. Res., 52, 947-968.

Brion, N. and G. Billen. 1998. Une réévaluation de la methode d'incorporation de $\mathrm{H}^{14} \mathrm{CO}_{3}^{-}$pour mesurer la nitrification autotrophe et son application pour estimer des biomasses de bacteries nitrifantes. Rev. Sci. Eau, 11, 283-302.

Eriksson, S. P. and R. C. Aller. 2001. Transient to steady biogeochemical succession in organic-rich marine sediment. ALSO Spring Meeting, Albuquerque, New Mexico.

Firestone, M. K., R. B. Firestone and J. M. Tiedje. 1980. Nitrous oxide from soil denitrification: factors controlling its biological production. Science, 208, 749-751.

Furukawa, Y., S. J. Bentley and D. L. Lavoie. 2001. Bioirrigation modeling in experimental benthic mesocosms. J. Mar. Res., 59, 417-452.

Gérino, M., R. C. Aller, C. Lee, J. K. Cochran, J. Y. Aller, M. A. Green and D. Hirschberg. 1998. 
Comparison of different tracers and methods used to quantify bioturbation during a spring bloom: 234-thorium, luminophores and Chlorophyll a. Estuar. Coast. Shelf Sci., 46, 531-547.

Gilbert, F., P. Bonin and G. Stora. 1995. Effect of bioturbation on denitrification in a marine sediment from the West Mediterranean littoral. Hydrobiologia, 304, 49-58.

Gilbert, F., G. Stora and P. Bonin. 1998. Influence of bioturbation on denitrification activity in Mediterranean coastal sediments: an in situ experimental approach. Mar. Ecol. Progr. Ser., 163, 99-107.

Green, M., R. C. Aller and J. Y. Aller. 1998. The influence of carbonate dissolution on the survival of shell-bearing meiobenthos in nearshore sediments. Limnol. Oceanogr., 43, 18-28.

Hall, P. O. J. and R. C. Aller. 1992. Rapid, small volume, flow injection analysis for $\Sigma \mathrm{CO}_{2}$ and $\mathrm{NH}_{4}^{+}$ in marine and freshwaters. Limnol. Oceanogr., 37, 1113-1119.

Henriksen, K. and M. W. Kemp. 1988. Nitrification in estuarine and coastal marine sediments: methods, patterns and regulating factors, in Nitrogen Cycling in Coastal Environments, T. H. Blackburn and J. Sørensen, eds., John Wiley and Sons, 207-249.

Huettel, M. and I. T. Webster. 2001. Porewater flow in permeable sediments, in The Benthic Boundary Layer: Transport Processes and Biogeochemistry, B. Boudreau and B. B. Jørgensen, eds., Oxford Press, 144-179.

Hulth, S., R. C. Aller and F. Gilbert. 1999. Coupled anoxic nitrification/manganese reduction in marine sediments. Geochim. Cosmochim. Acta, 63, 49-66.

Humphrey, A. E. 1972. The kinetics of biosystems: a review, in Chemical Reaction Engineering, R. F. Gould, ed., ACS Adv. Chemistry Ser., 109, 630-650.

Jahnke, R. A., S. R. Emerson and J. W. Murray. 1982. A model of oxygen reduction, denitrification, and organic matter mineralization in marine sediments. Limnol. Oceanogr., 27, 610-623.

Jørgensen, B. B. 2001. Life in the diffusive boundary layer, in The Benthic Boundary Layer: Transport Processes and Biogeochemistry, B. Boudreau and B. B. Jørgensen, eds., Oxford Press, 348-373.

Kapralek, F., E. Jechova and M. Otavova. 1982. Two sites of oxygen control in induced synthesis of respiratory nitrate reductase by Escherichia coli. J. Bact., 149, 1142-1145.

Knowles, R. 1982. Denitrification. Microbiol. Rev., 46, 43-70.

Koretsky, C. M., C. Meile and P. Van Cappellen. 2002. Quantifying bioirrigation using ecological parameters: a stochastic approach. Geochemical Transactions, 3, 17-30.

Kristensen, E. 1988. Benthic fauna and biogeochemical processes in marine sediments: microbial activities and fluxes, in Nitrogen Cycling in Coastal Environments, T. H. Blackburn and J. Sørensen, eds., John Wiley and Sons, 275-299.

Kristensen, E. and T. H. Blackburn. 1987. The fate of organic carbon and nitrogen in experimental marine sediment systems: Influence of bioturbation and anoxia. J. Mar. Res., 45, 231-257.

Kristensen, E., M. H. Jensen and R. C. Aller. 1991. Direct measurement of dissolved inorganic nitrogen exchange and denitrification in individual polychaete (Nereis virens) burrows. J. Mar. Res., 49, 355-377.

Kristensen, E., M. H. Jensen and T. K. Andersen. 1985. The impact of polychaete (Nereis virens Sars) burrows on nitrification and nitrate reduction in estuarine sediments. J. Exp. Mar. Biol. Ecol., 85, 75-91.

Li, Y. H. and S. Gregory. 1974. Diffusion of ions in seawater and deep-sea sediments. Geochim. Cosmochim. Acta, 38, 703-714.

Luther, G. W., III, B. Sundby, B. L. Lewis, P. J. Brendel and N. Silverberg. 1997. Interactions of manganese with the nitrogen cycle: alternative pathways to dinitrogen. Geochim. Cosmochim. Acta, 61, 4043-4052.

Mayer, M. S., L. S. Schaffner and W. M. Kemp. 1995. Nitrification potentials of benthic macrofaunal tubes and burrow walls: effects of sediment $\mathrm{NH}_{4}^{+}$and animal irrigation behavior. Mar. Ecol. Progr. Ser., 121, 157-169. 
Payne, W. J. 1976. Reduction of nitrogenous oxides by microorganisms. Bact. Rev., 37, 409-452.

Pelegri, S. P., L. P. Nielsen and T. H. Blackburn. 1994. Denitrification in estuarine sediment stimulated by the irrigation activity of the amphipod Corophium volutator. Mar. Ecol. Progr. Ser., 105, 285-290.

Rabouille, C. and J.-F. Gaillard. 1991. A coupled model representing the deep-sea organic carbon and oxygen consumption in surficial sediments. J. Geophys. Res., 96, 2761-2776.

Reichelt, A. C. 1991. Environmental effects of meiofaunal burrowing, in The Environmental Impact of Burrowing Animals and Animal Burrows, P. S. Meadows and A. Meadows, eds., A. Zool. Soc. London Symposia, 63, 33-52.

Revsbech, N. P., J. Sørensen and T. H. Blackburn. 1980. Distribution of oxygen in marine sediments measured with microelectrodes. Limnol. Oceanogr., 25, 403-411.

Ronan, T. E., Jr. 1978. Food-resources and the influence of spatial pattern on feeding in the phoronid Phoronopsis viridis. Biol. Bull., 154, 472-484.

Rysgaard, S., P. B. Christensen and L. P. Nielsen. 1995. Seasonal variation in nitrification and denitrification in estuarine sediment colonized by benthic microalgae and bioturbating infauna. Mar. Ecol. Progr. Ser., 126, 111-121.

Sayama, M. and Y. Kurihara. 1983. Relationship between burrowing activity of the polychaetous annelid, Neanthes Japonica (Izuka) and nitrification-denitrification processes in the sediments. J. Expl. Mar. Biol. Ecol., 72, 233-241.

Seitzinger, S. P. 1988. Denitrification in freshwater and coastal marine ecosystems: ecological and geochemical significance. Limnol. Oceanogr., 33, 702-724.

Seitzinger, S. P. and A. E. Giblin. 1996. Estimating denitrification in North Atlantic continental shelf sediments. Biogeochemistry, 35, 235-260.

Strickland, J. D. H. and T. R. Parsons. 1972. A practical handbook of sea water analysis. Bull. Fish. Res. Board Can., 169, 1-311.

Thamdrup, B. and T. Dalsgaard. 2000. The fate of ammonium in anoxic manganese oxide-rich marine sediment. Geochim. Cosmochim. Acta, 64, 4157-4164.

Tiedje, J. M., S. Sinkins and P. M. Groffman. 1989. Perspectives on measurement of denitrification in the fields including recommended protocols for acetylene based methods. Plant. Soil, 115, 261-284.

Ullman, W. J. and R. C. Aller. 1982. Diffusion coefficients in nearshore marine sediments. Limnol. Oceanogr., 27, 552-556.

Van Cappellen, P., J.-F. Gaillard and C. Rabouille. 1993. Biogeochemical transformation in sediments: kinetic models of early diagenesis, in Interactions of C, N, P and S Biogeochemical Cycles and Global Change, R. Wollast, F. T. Mackenzie and L. Chou, eds., NATO ASI Series, 401-445.

Van Cappellen, P. and Y. Wang. 1996. Cycling of iron and manganese in surface sediments: a general theory for the coupled transport and reaction of Carbon, Oxygen, Nitrogen, Sulfur, Iron and Manganese. Am. J. Sci., 296, 197-243.

Vanderborght, J. and G. Billen. 1975. Vertical distribution of nitrate concentration in interstitial water of marine sediments with nitrification and denitrification. Limnol. Oceanogr., 20, 953-961.

Woodin, S. A. and R. Marinelli. 1991. Biogenic habitat modification in marine sediments: the importance of species composition and activity, in The Environmental Impact of Burrowing Animals and Animal Burrows, P. S. Meadows and A. Meadows, eds., A. Zool. Soc. London Symposia, 63, 231-250. 